Research, part of a Special Feature on Implementing Participatory Water Management: Recent Advances in Theory, Practice and Evaluation

\title{
Facilitating Transitional Processes in Rigid Institutional Regimes for Water Management and Wetland Conservation: Experience from the Guadalquivir Estuary
}

\author{
$\underline{\text { Pablo F. Méndez }}^{1}, \underline{\text { Nicola Isendahl }}^{2}, \underline{\text { Jaime M. Amezaga }}^{3}$, and Luis Santamaría $^{1}$
}

\begin{abstract}
Traditional policies for water resources management and wetland conservation are often based on command-andcontrol approaches. The latter tend to drive the human-wetland-water system into pathological states, characterized by more vulnerable ecosystems and rigid institutions for governance. The overcoming of these states may rest in the development of flexible and adaptive institutional regimes that rely on adaptive governance and management. Because past factors might constrain the implementation of more flexible adaptive approaches to management, it is important to understand the historical mechanisms underlying the genesis of institutional rigidity. We first present the results of a historical analysis of Doñana, which can be characterized as a pathological water socio-ecosystem governed through rigid institutional regimes for water resources management and wetland conservation. In a second step, we analyze the advances achieved during a recent, large-scale restoration program for the Doñana wetlands, which adhered explicitly to the tenets of adaptive management. Our analysis indicated that the historical persistence of command-and-control approaches has been a path-dependent process that led to the emergence of a rigid institutional regime and caused it to enter a rigidity trap. However, the achievements of the restoration program suggest that a more flexible and adaptive regime could be developed through the introduction of adaptive management at the operational levels, using specifically tailored action research programs. To conclude, we speculate that the research strategy outlined could be extended to comply with, or complement, the requirements of the EU's Water Framework Directive in other European water socio-ecosystems.
\end{abstract}

Key Words: action research; adaptive cycle; adaptive management; command and control; Doñana; Guadalquivir Estuary; path dependence; rigid institutional regimes; Water Framework Directive

\section{INTRODUCTION}

Wetland ecosystems provide essential services to society, such as water storage, purification and supply, flood mitigation and erosion control, and stabilization of local climate conditions (Ramsar Convention Secretariat 2006). Hence, the sustainable use and management of wetlands and water resources is a widely acknowledged need (Davis and Froend 1999, Amezaga and Santamaría 2000, Folke 2003, Gleick 2003, Zedler and Kercher 2005, Millennium Ecosystem Assessment 2006, Vadineanu and Preda 2008). However, current policies for water resource management and wetland conservation (WRM and WC hereafter) are most often based upon the recurrent application of panaceas (e.g., blueprint solutions) that obviate the complex, variable, and uncertain nature of wetland ecosystems (Carpenter et al. 1999, Arrow et al. 2000, Scheffer et al. 2001, Brock and Carpenter 2007, Meinzen-Dick 2007). Such panaceas operate under two implicit assumptions: (1) a predictable biophysical world in static equilibrium, and (2) productivity can be maximized infinitely through the minimization of the effects of natural variability and the simplification, centralization, and compartmentalization of management operations (after Costanza et al. 1993, Carpenter and Gunderson 2001, Folke et al. 2005, Ostrom 2009, Pahl-
Wostl 2009). At their core, these types of policies are based on top-down, unique target command-and-control approaches that, although sometimes leading to short-term improvements, ultimately drive the whole human-wetland-water system into undesirable, pathological states characterized by: (1) more vulnerable, i.e., less resilient, aquatic ecosystems, (2) rigid institutions for governance, distrusted by local societies, and (3) economies that become highly dependent on limited sets of resources (sensu Holling and Meffe 1996, Olsson et al. 2006, Beier et al. 2009).

To overcome these constraints, two factors must converge. Firstly, because humans are crucial components of the system and directly affect its trajectory, the coupled and complex nature of human institutions, wetlands ecosystems, and water resources must be recognized, and such understanding incorporated into operative policies, for example through their conceptualization as integrated water socio-ecosystems (WSES hereafter) (after Anderies et al. 2004, Berkes et al. 2003, Janssen et al. 2007, Norberg and Cumming 2008). Secondly, the creation of more flexible and adaptive institutional regimes in which reactive, command-and-control responses to uncertainty and unpredictability are replaced by proactive, structured, and informed decision making processes

\footnotetext{
${ }^{1}$ Laboratory of Spatial Ecology, Mediterranean Institute for Advanced Studies (Spanish Research Council, University of the Balearic Islands), ${ }^{2}$ Institute of Environmental Systems Research (University of Osnabrück), ${ }^{3}$ Institute for Research on Environment and Sustainability, University of Newcastle
} 
may require the gradual implementation of transitional processes (Gunderson and Light 2006, Pahl-Wostl 2007).

Such regimes are based on adaptive governance, an emergent framework for the management of complex socio-ecosystems aimed at integrating science, policy, and decision making (Folke et al. 2005, Brunner et al. 2006). This framework postulates the need for organizing governance around systems of organizations, polycentric institutional arrangements, and networks of individuals with self-organization and selfenforcing capabilities, in order to achieve an optimal balance between decentralized and centralized control (Folke et al. 2005). At the management and technical levels, they rely on the implementation of adaptive management, a critical component of adaptive governance that involves: (1) continual, participatory processes aimed at rationally defining problems and developing solutions, (2) structured representation of knowledge and evaluation of scenarios by means of dynamic models, and (3) identification of uncertainties and alternative hypotheses to be tested through a structured process of investigation, in which policy failure is acknowledged as a source of learning (Holling 1978, Walters and Hilborn 1978, Walters 1986, Lee 1993, Lee 1999, Gregory et al. 2006, Polasky et al. 2011).

In summary, while adaptive management aims to reduce our ignorance by using direct management actions as experiments to test implemented policies at the operational levels, adaptive governance deals with the institutional barriers and opportunities to the implementation of adaptive management (Gunderson and Light 2006). Indeed, adaptive management often encounters institutional factors (e.g., rules, organizational structures, shared ideas and paradigms, individual attitudes) that may undermine the chances of its successful implementation (McLain and Lee 1996, Walters 1997, Gunderson 1999, Noble 2000, Lee 2003, Walkerden 2005, Marmorek et al. 2006, Folke et al. 2007, Méndez et al. 2010). This risk is particularly pronounced in pathological WSES; hence, it is of utmost importance to understand both their rigid institutional configuration and the historical mechanisms underlying the genesis of rigidity, in order to facilitate potential transitions to more flexible and adaptive institutional regimes.

As part of a wider, long-term research program, we present the results of a historical institutional analysis of the Doñana region, which we propose as a case study of pathological WSES governed through rigid institutional regimes for WRM and WC. We first outline the research program, its general aims, and the specific objectives of the historical analysis. Then we present the methods used, followed by the results, which are presented as a systems narrative that synthesizes our interpretation of the genesis and evolution of the institutional regimes. In a second step of investigation, we analyze and discuss the advances achieved during a recent, large-scale restoration program for the Doñana wetlands, which adhered explicitly to the tenets of adaptive management. In the closure of the article, we speculate on the potential extension of our research strategy to comply with, or complement, the requirements of the European Union's Water Framework Directive at other European WSES, and propose future research needs.

\section{RESEARCH SITE AND OBJECTIVES}

Doñana is located in the right bank of the Guadalquivir Estuary (south-west Spain). During the last two centuries, the Guadalquivir's marsh and floodplain wetlands have been modified by the intensification of agriculture and water resource use, compounded in the last decades by accelerated tourism, infrastructure, and urban development. The result is a fragmented wetland that has lost most of its original extension and complexity (Amezaga and Santamaría 2000, Fernández and Pradas 2000a, Fernández-Delgado 2006, García and Marín 2006, Méndez et al. 2010). Such changes, along with other developments at the basin level (e.g., metalliferous mining, fluvial navigation), have bequeathed to the region increasing environmental hazards, nature conservation threats, and physical pressures (e.g., overextraction of groundwater, waterfowl mortalities, biological invasions), as well as intricate conflicts in the social realm (e.g., struggles with cattle and horse breeders, furtive hunting, economic dependence on external subsidies) (Amezaga and Santamaría 2000, González-Arteaga 2005, Fernández-Delgado 2006, Tablado et al. 2010, Martín-López et al. 2011, Palomo et al. 2011). Our long-term research program paralleled the implementation of the large restoration projects, "Guadiamar's Green Corridor" and "Doñana 2005", launched in response to the accidental collapse of the tailings dam of "Los Frailes" zinc mines in 1998 (Meharg et al. 1999, Taggart et al. 2004). Both projects adhered explicitly to adaptive management tenets (Montes 2002, García and Marín 2006, Santamaría et al. 2006). Our program focused on identifying the institutional constraints and opportunities for the full development of such tenets.

Overall, the program aims to: (1) use historical and current knowledge to understand and explain Doñana's rigid institutional regimes, (2) provide, on the basis of these results, general policy guidance and specific recommendations for a managed transition towards more flexible and adaptive regimes, (3) carry out a coupled action-research program that facilitates actor involvement in the potential transition, while documenting and developing both. In particular, we wanted to evaluate whether adaptive management could be introduced at the regime's operational levels, in particular, at the researchmanagement interface, and whether it represents a significant avenue for the resolution of the long-standing conflict between WRM and $\mathrm{WC}$ in the region.

The specific objectives of the historical analysis presented in this article were: 
Table 1. Summary of methods.

\begin{tabular}{|c|c|c|c|}
\hline Methodological approach & Application to research & Rationale of use & Specific methods \\
\hline Single case study & Overall research program & $\begin{array}{l}\text { - Exploratory character of whole research program } \\
\text { - Representative case of pathological WSES } \\
\text { governed through a RIR, hence informative for } \\
\text { other pathological systems } \\
\text { - Generalization of results to theory, not to } \\
\text { populations (i.e., analytical generalization) } \\
\text { - Instrumental for the normative goal of } \\
\text { elaborating policy-relevant recommendations } \\
\text { - Replication if evidence is found in other cases }\end{array}$ & $\begin{array}{l}\text { Embedded design (Yin 2008): } \\
\text { - Case study: Doñana WSES } \\
\text { - Context: Guadalquivir Estuary } \\
\text { - Three subunits of analysis: the hydro- } \\
\text { ecological system (not analyzed here) and } \\
\text { the institutional regimes for WRM and WC } \\
\text { (the focus of the present analysis) }\end{array}$ \\
\hline $\begin{array}{l}\text { Theoretical framework } \\
\text { development }\end{array}$ & $\begin{array}{l}\text { Overall research program. } \\
\text { Circumscribed here to the } \\
\text { historical analysis }\end{array}$ & $\begin{array}{l}\text { - Propositional conceptualization of RIR, liable to } \\
\text { empirical evaluation } \\
\text { - Guide analysis and inform interpretations, } \\
\text { departing from a reasoned selection of existing } \\
\text { theory } \\
\text { - Hypotheses derived deductively provide } \\
\text { framework with explanatory power } \\
\text { - Ground the inquiry in updated theory, allows for } \\
\text { a characterization of initial institutional conditions } \\
\text { and potential transitions }\end{array}$ & $\begin{array}{l}\text { Inductive and deductive inference } \\
\text { procedures (see Thelen } 1999 \text { for a } \\
\text { description of the use of both procedures in } \\
\text { different institutionalism disciplines; } \\
\text { Campbell and Pedersen } 2001 \text { for the } \\
\text { application of both procedures in several } \\
\text { case studies using institutional analysis; } \\
\text { Holling and Allen } 2002 \text { for a depiction of } \\
\text { "adaptive inference" in ecology, a method } \\
\text { that employs both procedures at different } \\
\text { stages of empirical evidence evaluation) }\end{array}$ \\
\hline Systems narrative & Historical analysis & $\begin{array}{l}\text { Instrumental for: } \\
\text { - Understanding and describing the history and } \\
\text { genesis of the institutional regimes } \\
\text { - Addressing and embracing (vs. rejecting) the } \\
\text { inherent complexity of WSES } \\
\text { - Assessing theoretical framework applicability } \\
\text { - Evaluating } h_{l} \\
\text { - Informing future analyses of current institutional } \\
\text { configuration }\end{array}$ & $\begin{array}{l}\text { - Data collection and categorization through } \\
\text { directed, deductive content analysis (see, e. } \\
\text { g., Hsieh and Shannon 2005) } \\
\text { - Data analysis and interpretation (see e.g., } \\
\text { Allison and Hobbs 2004, Beier et al. 2009, } \\
\text { for different approaches to constructing a } \\
\text { systems narrative) }\end{array}$ \\
\hline Action research & $\begin{array}{l}\text { Overall research program. } \\
\text { Informed by the historical } \\
\text { analysis }\end{array}$ & $\begin{array}{l}\text { Instrumental for: } \\
\text { - Introducing new modes of actor involvement and } \\
\text { collaborative understanding of current institutional } \\
\text { problems } \\
\text { - Facilitating the long-term transition towards } \\
\text { more adaptive and flexible institutional regimes } \\
\text { - Gathering qualitative data for future analyses of } \\
\text { current institutional configuration (e.g., } \\
\text { management narratives) }\end{array}$ & $\begin{array}{l}\text { We employed the following methods (see } \\
\text { Appendix } 2 \text { for a detailed description): } \\
\text { - Actor identification (see e.g., Mostert } \\
\text { 2006) } \\
\text { - Semi-structured, open-ended interviews } \\
\text { (Robson 2002) } \\
\text { - Workshops including: thematic talks, } \\
\text { facilitated discussion, and Group Model } \\
\text { Building (Vennix 1996) and Card Sorting } \\
\text { (Hare and Pahl-Wostl 2002) methods in } \\
\text { focus groups }\end{array}$ \\
\hline
\end{tabular}

- To understand and explain the genesis of institutional rigidity in Doñana.

- To assess the applicability of the theoretical framework presented in the methods section.

- To inform our action-research program (e.g., deriving historical criteria for actor analysis from the historical analysis), as well as future analyses about the current configuration of the institutional regimes.

\section{METHODS}

The methodology employed in the historical analysis consisted of the construction of a systems narrative interpreting the genesis of Doñana's institutional regimes for WRM and WC and, in particular, of their rigidity. The next sections describe the methods employed in our research program, with a focus on the construction of the narrative (see Table 1 for a summary).

\section{Single case study research approach}

We chose to analyze Doñana as a single case study because (1) Doñana constituted a "critical case" (sensu Yin 2008:47) to test the applicability of our theoretical framework; (2) this approach was instrumental for accomplishing our long-term goal of providing specific policy-relevant recommendations for a managed transition in Doñana. As a consequence, our results can be generalized to theory, not to "populations or universes" (i.e., analytical generalization, Yin 2008:15). Theory is used as a template with which to compare the empirical results of the case study. Replication can be claimed if evidence from two or more cases is shown to support such theory (Yin 2008). 
Fig. 1. The Institutional Analysis and Development framework, applied to the Doñana water socio-ecosystem (adapted from Ostrom et al. 1994 with permission from The University of Michigan Press, Ann Arbor, Michigan, USA).

EXOGENOUS VARIABLES

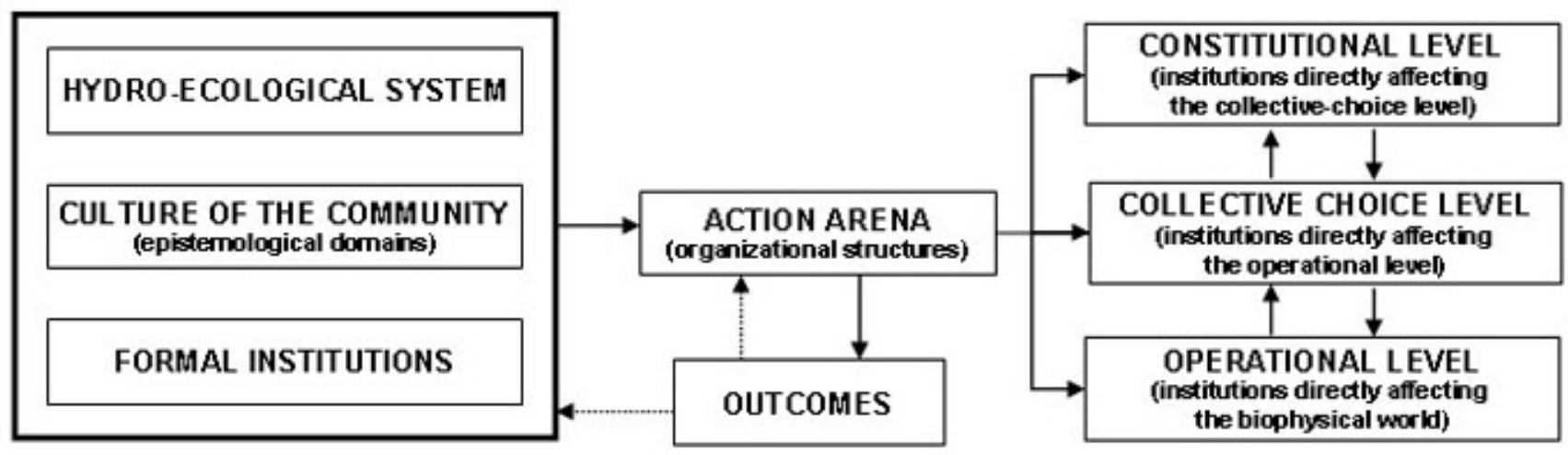

\section{Theoretical framework}

Propositional conceptualization of rigid institutional regimes For the purpose of the analysis presented here, which has an exploratory and systemic character, institutional regimes were conceptualized as the on-the-ground matrix of institutions, organizational structures, and epistemological domains that define policy formation, decision-making procedures and required action or outcomes for the accomplishment of a certain societal function, in this case, WRM and WC (based on Gunderson et al. 1995, Holling and Meffe 1996, Ostrom 2005, Hotimsky et al. 2006, Pahl-Wostl 2007, FischerKowalski and Rotmans 2009). We chose to organize the analysis using the Institutional Analysis and Development framework (IAD) (Figure 1; Ostrom et al. 1994), due to its descriptive power, analytical versatility and theoretical interoperability (Clement 2010, Poteete et al. 2010). According to it, institutions are the formal and informal prescriptions (i.e., rules-in-use) about what actions or states of the world are required, prohibited, or permitted. Actors use these prescriptions to organize repetitive and structured interactions while participating in action situations within the regime's action arenas, at three different levels (see Fig. 1). Institutions are considered as an exogenous variable of the arena; other exogenous variables include the biophysical system being acted upon, in this case Doñana's hydroecological system, and the culture of the community (Ostrom 2005). The latter is a very broad and relevant concept, considered as an institution itself by sociological disciplines (see Hall and Taylor 1996). For this analysis, we considered epistemological domains (e.g., scientific-technical approaches, traditional ecological knowledge) as a sufficient observable element for understanding the formation of the RIR and left out the more general concept of culture, which will be analyzed in subsequent studies of the current institutional configuration.
Organizational structures (e.g., management and enforcing agencies, property systems) were considered as a response to the institutional matrix of the system (sensu North 1990a), occurring at the action-arena level.

Insights and evidence about Doñana drawn from the literature, as well as our own informal observations and comparisons ("empirical puzzles", sensu Thelen 1999) over two decades of field work in both the ecological and social grounds (e.g., Santamaría et al. 1996, Santamaría and Amezaga 1999, Amezaga and Santamaría 2000), led us early in 2006 to think that the region fitted the features of a pathological WSES. Through inductive reasoning, we therefore assumed the presence of rigid institutions for WRM and WC based on topdown, command-and-control approaches (see also GómezBaggethun and Kelemen 2008). Subsequently, we started to develop, following a deductive approach, a formal and testable conceptualization of rigid institutions on the basis of preexisting concepts from the literature (see e.g., "prediction and control regime"; Moberg and Galaz 2005, Pahl-Wostl 2007). We crystallized this conceptualization under the term rigid institutional regime (RIR hereafter) and established its fundamental properties by integrating the main features defining command-and-control approaches, namely:

- Decision making and required actions or outcomes are determined hierarchically and top-down (i.e., authoritatively).

- Public participation and, more specifically, actor involvement processes are determined narrowly and passively.

- Power distance, individualism, avoidance of uncertainty, and short-term maximization (vs. long-term optimization) are promoted. 
Fig. 2. The adaptive cycle. Modified from Holling and Gunderson (2002) with permission from Island Press, Washington, D. C., USA.

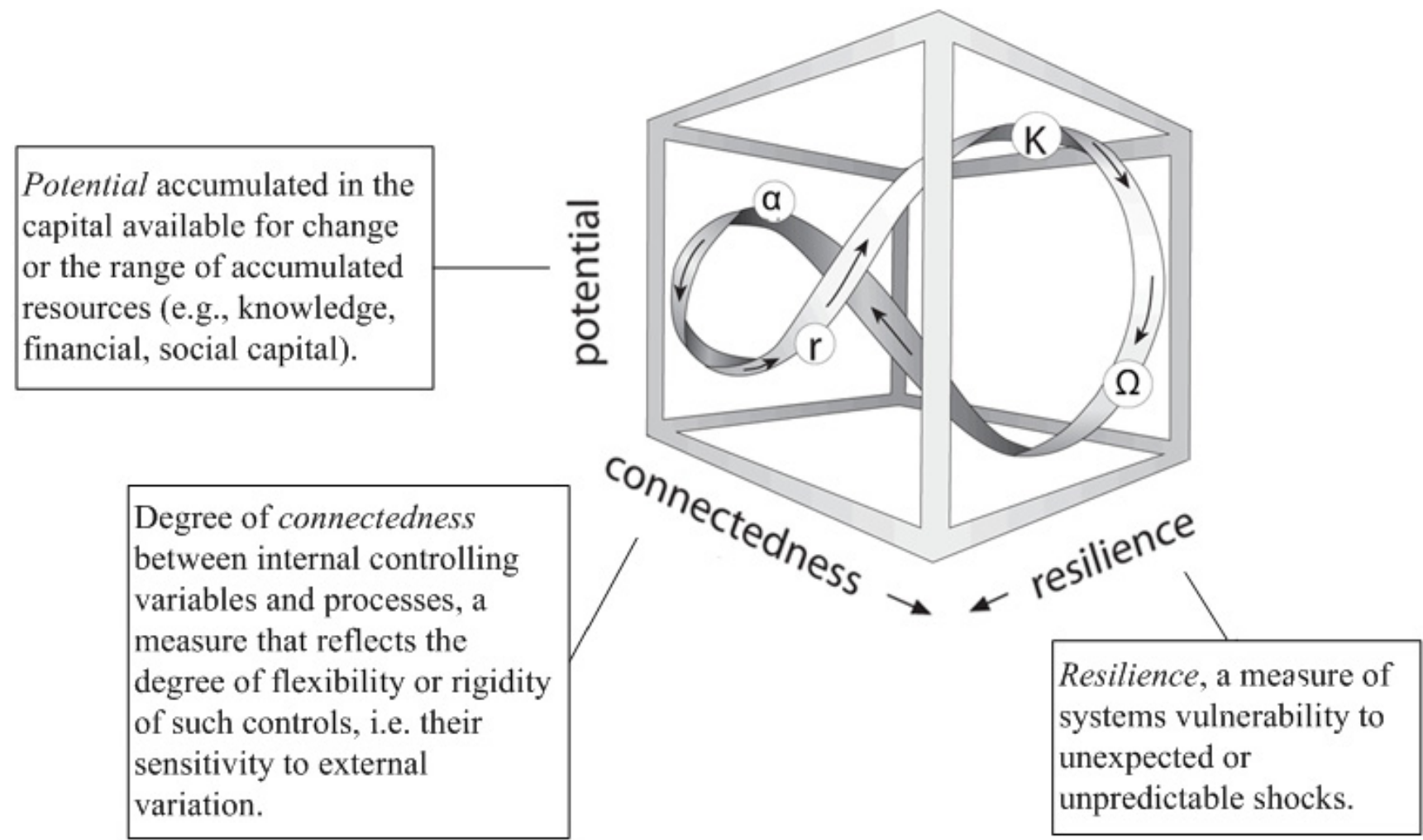

- The recurrent generation of structural entities (e.g., infrastructure for water control) in which maintenance costs exceed their long-term benefits.

The adaptive cycle

Evidence from case studies of regional development and resource use has shown that complex adaptive systems undergo cyclic, multistate catastrophic behavior (Levin 1998) that fit an adaptive four-phase cycle, along which structural changes among the system's descriptive properties, i.e. potential, connectedness, and resilience (Figure 2) (Holling 1986, Gunderson et al. 1995, Gunderson and Holling 2002). Although the adaptive cycle is a heuristic that was originally applied to resource systems and ecosystems, it has been generalized to coupled social-ecological systems and single social systems (e.g., institutional regimes), which would undergo, in principle, similar phases (Table 2) (Holling and Gunderson 2002, Allison and Hobbs 2004, Cumming and Collier 2005, Walker and Lawson 2006, Beier et al. 2009, Bunce et al. 2009, Daedlow et al. 2011). We postulate that the Doñana's regimes for WRM and WC fitted the adaptive cycle at least once through their histories; hence, the structural changes in the system's descriptive properties (potential, connectedness, and resilience) can be used to describe the forces that shaped the behavior of such regimes.

The meaning of resilience, in particular, can be approached from two different perspectives: "engineering resilience" (Holling 1996) and "ecological resilience" (Holling 1973). While the first focuses on the notion of time for recovering after disturbance, i.e., returning to equilibrium (Walker et al. 2004), the second focuses in the probability of multiple stable states, and is defined as the capacity of ecosystems "to absorb disturbance and reorganize while undergoing change so as to still retain essentially the same function, structure, identity, and feedbacks", a definition that may be applied to the socioecosystem as a whole (Walker et al. 2004). From the latter, it can be derived a definition of "institutional resilience" that is instrumental for the purposes of our analysis: the capacity of institutional regimes ("resilience of what") to withstand external disturbances (e.g., environmental perturbation, political changes; "resilience to what") without losing the performance capacity for the accomplishment of the societal function for which that they were devised (after Adger 2000, Carpenter et al. 2001, Perrings 2006, Baral et al. 2010, Smith and Stirling 2010). 
Table 2. Description of the four phases of the adaptive cycle and the associated changes in the system's descriptive properties: potential for change, connectedness, and resilience (Gunderson and Holling 2002).

\begin{tabular}{|c|c|c|c|c|}
\hline Phase & Description & Potential for change & Connectedness & Resilience \\
\hline$\alpha$ (reorganization) & $\begin{array}{l}\text { - System widely open to reorganization } \\
\text { - Experimentation and initial establishment of } \\
\text { actors, organizations and institutions, strongly } \\
\text { subjected to evolutionary forces (i.e., competition, } \\
\text { failure, survival) } \\
\text { - Loss of resources (e.g., energy, information) is } \\
\text { minimized, so that they become available in r } \\
\text { phase (legacies) } \\
\text { - Great uncertainty about options for the future and } \\
\text { chance for unexpected forms of renewal }\end{array}$ & $\begin{array}{l}\text { Relatively high for future } \\
\text { development. }\end{array}$ & $\begin{array}{l}\text { Low. Internal regulation } \\
\text { and control over external } \\
\text { variability is weak. }\end{array}$ & $\begin{array}{l}\text { High. Wide stability } \\
\text { region and weak } \\
\text { regulation around } \\
\text { equilibria. }\end{array}$ \\
\hline $\begin{array}{l}\mathrm{r} \\
\text { (exploitation and } \\
\text { rapid growth) }\end{array}$ & $\begin{array}{l}\text { - Innovators perceive unlimited opportunity } \\
\text { - Bases for entrepreneurial and market competition } \\
\text { are settled } \\
\text { - External variability remains, favorable to entities } \\
\text { more adapted to it (r-strategists) } \\
\text { - Incremental exploitation of available resources } \\
\text { and growth } \\
\text { - Actors develop capacity for controlling external } \\
\text { variability, hence reinforcing their own expansion } \\
\text { - Future starts to be more predictable }\end{array}$ & $\begin{array}{l}\text { Declines as resources } \\
\text { start and continue to be } \\
\text { exploited. }\end{array}$ & $\begin{array}{l}\text { Still low, but starts to } \\
\text { increase, along with } \\
\text { stability. }\end{array}$ & $\begin{array}{l}\text { Remains high due to the } \\
\text { adaptation to high } \\
\text { variability. }\end{array}$ \\
\hline $\begin{array}{l}\mathrm{K} \\
\text { (consolidation and } \\
\text { conservation) }\end{array}$ & $\begin{array}{l}\text { - Growth rate slows down } \\
\text { - Reduced opportunity and difficulties for new } \\
\text { entrants } \\
\text { - The future seems ever more certain and } \\
\text { determined } \\
\text { - Competitive edge shifts to those that control } \\
\text { variability (K-strategists) } \\
\text { - Increasing returns from efficiency (e.g., } \\
\text { minimizing costs, streamlining operations) } \\
\text { - Organizations become bureaucratized, rigid and } \\
\text { internally focused (i.e., blind to external changes) }\end{array}$ & $\begin{array}{l}\text { Becomes high again in } \\
\text { terms of stored capital }\end{array}$ & $\begin{array}{l}\text { Increases as system } \\
\text { becomes highly stable } \\
\text { and over-connected in } \\
\text { structural and } \\
\text { organizational terms, } \\
\text { hence more rigid (less } \\
\text { flexible). }\end{array}$ & $\begin{array}{l}\text { Rapidly declines, i.e., } \\
\text { vulnerability to external } \\
\text { disturbance starts to } \\
\text { increase. }\end{array}$ \\
\hline $\begin{array}{l}\Omega \\
\text { (release) }\end{array}$ & $\begin{array}{l}\text { - Extreme structural rigidity that may trigger } \\
\text { sudden change, collapse and a "creative } \\
\text { destruction" phase (Schumpeter 1950) } \\
\text { - Chaotic behavior, uncertainty rules govern } \\
\text { - All of these create the source for reorganization } \\
\text { and the systems begin to acquire a new identity }\end{array}$ & $\begin{array}{l}\text { Suddenly declines as } \\
\text { previously accumulated } \\
\text { resources are abruptly } \\
\text { released and exhausted. }\end{array}$ & $\begin{array}{l}\text { High, but connections } \\
\text { and regulatory controls } \\
\text { are suddenly broken. }\end{array}$ & $\begin{array}{l}\text { Low, but rapidly } \\
\text { increases as the system } \\
\text { moves towards the next } \alpha \\
\text { phase of reorganization. }\end{array}$ \\
\hline
\end{tabular}

We consciously excluded from our framework the work on panarchical (i.e., cross-scale) interrelationships and maladaptive traps (e.g., rigidity and poverty trap, Holling et al. 2002; lock-in trap, Allison and Hobbs 2004), to avoid potential biases in our interpretations. Instead of including the traps a priori in our theoretical framework, we decided to let the potential patterns of such traps arise analytically and, in such case, discuss them a posteriori and lay the foundations for further research needs. Our aim was to avoid the selective use of theoretical concepts or the imposition of an explanatory framework upon data analysis (sensu Layder 1998).

\section{Institutional path dependence}

Path dependence is a highly abstract concept that cannot be established independent of theory, and must be previously objectified. We undertook such a task through the coherent integration of concepts borrowed from both economics and historical institutionalism. According to them, institutional regimes can be understood as entities impacted, at certain points in history, by the effect of two types of events: (1) At so-called "critical junctures", strong systematic forces may have fundamental impacts on the regime's subsequent dynamics (Thelen 1999). Depending on the way they occur, they may produce radical or incremental changes that result in a diversity of institutional configurations, therefore shaping large political or economic development transitions in the long run (Collier and Collier 1991, Hacker 1998, Mahoney and Thelen 2010); (2) At any point in history, including at critical junctures, seemingly small events may have disproportionate consequences (i.e., exhibit nonlinearity) due to self-enforcing mechanisms (Hacker 1998). These mechanisms are often characterized by what economists know as "increasing returns" (North 1990b, Arthur 1999), highlighting how the probability of events throughout a historical path increases with each step until an equilibrium configuration is reached (Mahoney 2000).

In the first case (critical junctures), path independence is expected: change occurs in response to certain mechanisms (e.g., negative feedback, competitive selection) that preclude 
deviations from configurations logically expected by operating theories, the most salient ones being those based on neoclassical economic principles, the so-called efficiency baseline (Hacker 1998, Mahoney 2000).

In the second case, "increasing-returns" mechanisms entail positive feedbacks that may increase the probability of occurrence of certain institutional arrangements. Once such arrangements prevail, they are very resistant to change, that is, they are "difficult to exit from" (North 1990b) and may lead, in turn, to lock-in situations in which a "winning", stableequilibrium configuration becomes very costly to reverse -, regardless of the efficiency of alternative, even probable, configurations (Pierson 1993, Ikenberry 1994, Hacker 1998, Thelen 1999). Ultimately, such a configuration enters a path of institutional development characterized by institutional reproduction and continuity, which may become further reinforced by: (1) the structural constraints of its immediate past (e.g., infrastructure, institutions), or (2) the subsequent decisions, choices and coordination efforts exerted by on-theground, inner actors through agency (e.g., policy networks, lobbies) in ways that reflect and reinforce the "inherent logic" of the system (Thelen 1999, Mahoney 2000).

These processes are path dependent and have the following fundamental properties (North 1990b, Arthur 1994, Arthur 1999, Thelen 1999, David 2000, Mahoney 2000, Pierson 2000):

- Self-enforcing mechanisms, such as: (1) large setup or fixed costs, which create a high pay-off for further investment in a single option, (2) learning effects, if knowledge gained in the recursive operation over the resource system or ecosystem leads actors to be more efficient and get higher returns from continuing use, (3) coordination effects, if the individual benefit increases as others adopt the same option, and (4) functional, power and legitimation mechanisms.

- Contingency. Theory is unable to explain, either deterministically or probabilistically, the emergence of the resultant institutional outcomes on the basis of their initial conditions, i.e., owing to their inefficiency as compared with alternative outcomes, current outcomes are not logically expected.

- Timing and sequencing. The order of events may be determinant, since early events have larger effects than later ones.

- Inertia. Once in place, winning configurations can remain "on stage" in the absence of the forces that originated them due, for example, to institutional reproduction mechanisms.

\section{Hypotheses}

We completed our theoretical framework by deducing a specific hypothesis $\left(h_{l}\right)$ addressing the causal mechanisms underlying the genesis of the assumed institutional outcome (i.e., the RIR), and complemented it with a working hypothesis $\left(H_{l}\right)$ that will guide our long-term inquiry. Both hypotheses were stated as follows:

$h_{l}$ : The historical persistence of command-and-control approaches is a path dependent process that has led to the emergence of a rigid institutional regime in the Doñana water socio-ecosystem, and caused it to enter and get trapped in a pathological stable state. The null hypothesis $\left(h_{0}\right)$ would be that of process path independence.

$H_{l}$ : The development of action-research programs is instrumental for implementing adaptive management at the operational levels in pathological WSES, since it facilitates the long-term transition from RIR to more flexible and adaptive institutional regimes for WRM and WC. The null hypothesis $\left(H_{0}\right)$ would be that of non-instrumentality of action research.

\section{Data collection, categorization and analysis}

Qualitative historical data (hereafter referred to as "institutional events") were collected from a number of historic accounts about the Doñana WSES or about relevant events affecting it, included in grey and published literature (see Appendix 1). We classified and structured the raw data using directed, deductive content analysis (see e.g., Hsieh and Shannon 2005). We used a broad conceptual categorization matrix, composed of two nominal categories (key institutions and main policy, economic, organizational and scientifictechnical features), crossed with the historical period at which each institutional event took place (based on classical denominations of Spanish historiography, see e.g., Domínguez-Ortiz 2000). The nominal categories constituted integrative surrogates to both observe the general components of the institutional regimes (i.e., institutions, organizational structures, and epistemological domains) and infer the propositional features (e.g., hierarchical decision making, power distance, "white elephants") that characterize RIRs at a more abstract level of analysis. After the elaboration of the systems narrative (see Systems Narrative section), we complemented the historical profile of the matrix with the identification of corresponding phases of the adaptive cycle (cycle's phase). The complete matrix is presented in Appendix 1.

Data analysis and interpretation (i.e., systems narrative construction; see e.g., Allison and Hobbs 2004) were performed in a back-and-forth fashion between both stages. This recursive process allowed us to become familiarized with the data, while looking for evidence and patterns that matched or mismatched our theoretical propositions. Specifically, we focused on:

- The identification of adaptive cycle phases fitting the evolution of the WRM and WC regimes. 
- The description of the dynamics of their descriptive properties (potential, connectedness, and resilience), with a specific focus on institutional resilience.

- The identification of critical junctures and their effects over the historical trajectory of both regimes.

- The search for proof of path dependence (e.g., selfenforcing mechanisms), specially with reference to command-and-control, technocratic approaches.

- The qualitative evaluation of $h_{l}$.

- The development of a historical criterion for actor analysis, to be subsequently used in the action-research program (see Appendix 2).

\section{SYSTEMS NARRATIVE: HISTORICAL INTERPRETATION}

We firstly present two separated narratives for the period between the end of the $18^{\text {th }}$ century and 1969 , which respectively interpret the foundation and development of the Doñana's institutional regimes for WRM and WC. Secondly, we present a joint narrative for the period 1970-2000, which interprets how both regimes operated separately, but in synchrony, due to their common foundation upon commandand-control institutional approaches (see Figure 3 for a diagrammatic representation of the narratives, including examples from the most salient institutional events). Thirdly, we present a narrative for the period 2000-2008, contextualizing the current characteristics of both regimes within the Los Frailes mining accident and our long-term research program.

\section{From the end of the 18th century until 1969}

\section{Water resource management}

The intensive transformation of Doñana did not start until the 1920s; however, the roots of its current institutional regime for WRM can be traced back to the end of the $18^{\text {th }}$ century. At that time, organizational structures for water planning and management in the Guadalquivir Estuary were still based on the implementation of scattered projects for the construction and maintenance of a rudimentary infrastructure for water distribution and use, i.e., on the marginal control of water. Overall, the ruling regime was characterized by a rather stable, self-sufficient and sustainable economy based on local and traditional ecological knowledge, which had limited impacts on the estuary's hydro-ecological system. Such a regime corresponded to the last stages of an r-K phase (Figure 3, point 1), during which local pioneers (r-strategists) became adapted to external variability, expanded incrementally and accumulated capital from the extraction of water resources, until reaching a stable exploitation pattern in which competition was starting to take place. The ensuing $\mathrm{K}$ phase was arranged around an archaic property system and formal institutions empowering the governing nobility (K-strategists) to regulate and organize the use of water resources.
At this stage, the regime showed limited resilience to: (1) the national, enlightened-absolutist socioeconomic trends of the époque, which promoted navigability and economic development in the estuary; and (2) the top-down, constitutional, deficit-driven impositions enforced by State officials. We argue that this was caused by two main mechanisms. On the one hand, internal stability was disturbed from inside, particularly at the operational level, where a number of key private entrepreneurs effectively promoted their view of the entire hydro-ecological system as an underexploited region with enormous potential (i.e., lowreleased capital). On the other hand, the regime was characterized by a general void of inter-scale, collectivechoice action arenas (e.g., "weak socioeconomic structures", Moral-Ituarte 1991) for the cooperative definition of more equitable formal rules for resource use and management (e.g., uniting the governing nobility and the local administrations). This void precluded the development of interconnected decision making processes and multilevel action arenas within the regime, i.e., it resulted in low connectedness that lowered its institutional resilience.

In system terms, the institutional regime lacked the necessary internal regulation and control for absorbing external disturbances, and was highly sensitive to the free will of some internal entrepreneurs. This resulted in a system-wide institutional collapse ( $\Omega$ phase; Fig. 3, point 2 ), after which the entrepreneurs started to target the large-scale modification of the hydro-ecological system, and to progressively restructure the regime around a novel, alternative configuration ( $\alpha$ phase; Fig. 3, point 3 ). The first plans and projects aiming at the transformation of the estuary into navigable watercourses and the marshes into productive cropland were developed. Although they were not implemented immediately in Doñana (e.g., disentitlements were only applied to surrounding scrubland and forest properties), they represented the first organized attempts to turn the region into an economically productive land, a Schumpeterian "creative destruction" phase (Schumpeter 1950:83).

By the mid $19^{\text {th }}$ century, the regime had entered a new $r$ phase (Fig. 3, point 4), characterized by the positive feedback between new constitutional institutions and local events. Royal governments transferred common property rights to actors at lower, collective choice and operational levels, allowing them to dedicate large individual and cooperative efforts to promote the new economic productivity perspectives, from both the public and the private sectors. During the second half of the century, this process was reinforced by new institutions and strategies, including the progressive increase of organized middle class actors and sophisticated technological projects, necessary to tackle the high investment costs and long-term recouping required for the transformation of marshland into irrigated cropland. 
Fig. 3. Historical development of Doñana's institutional regimes for water resource management (WRM) and wetland conservation (WC), interpreted through the adaptive-cycle heuristic, and concomitant changes in institutional resilience. Dates and description profiles of institutional events are provided in Appendix 1.

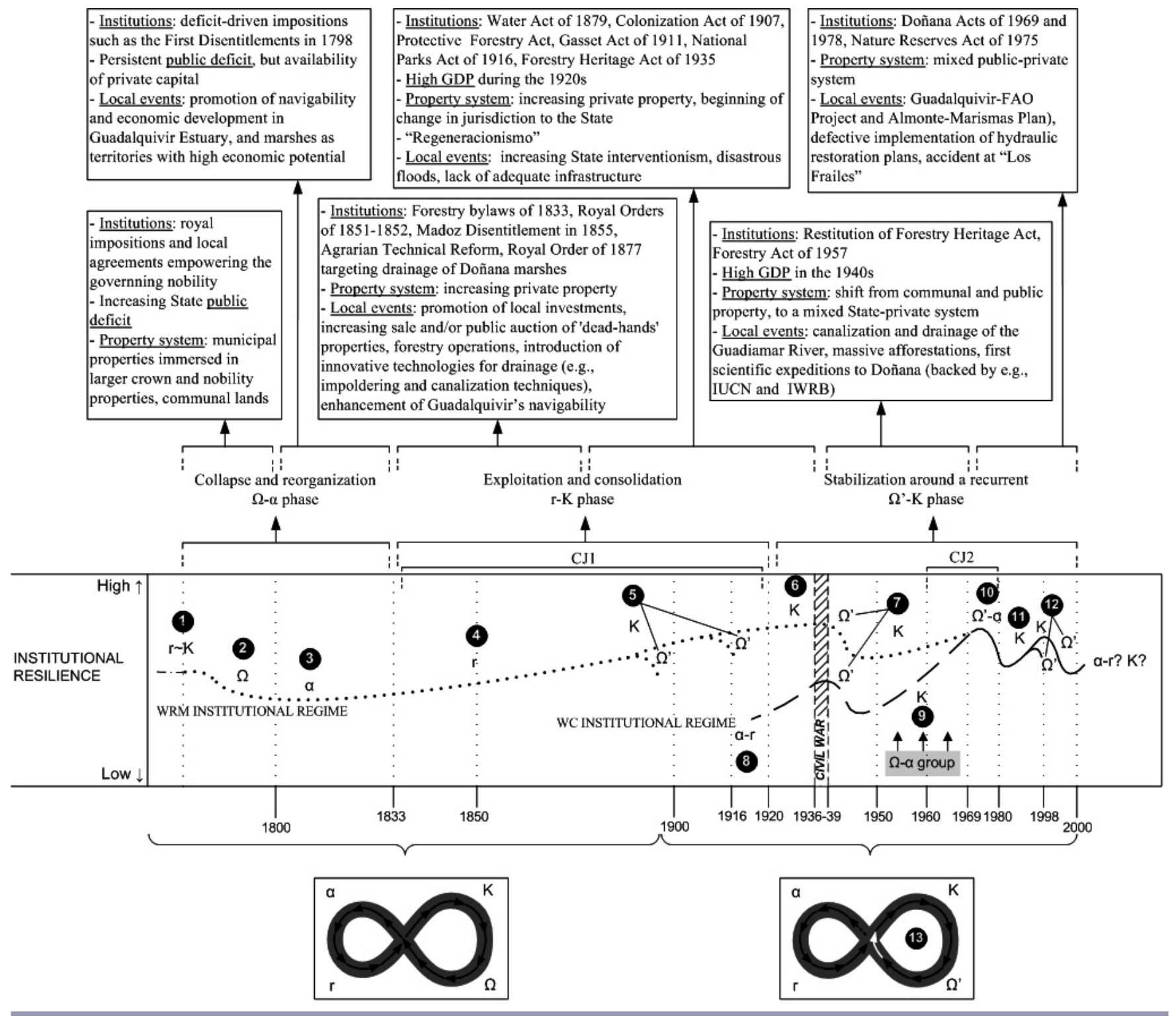

At the end of the $19^{\text {th }}$ century and the outset of the $20^{\text {th }}$, the regime started to stabilize around a $\mathrm{K}$ phase (Fig. 3, point 5), with the support of newly formed institutions at the constitutional level and intellectual-scientific movements that encouraged large hydraulic modifications at the national level (regeneracionismo, see e.g. Orti 1984). During this period, the social and economic costs and risks associated with technological failures did not seem to represent a major limiting factor for actors at the collective choice and operational levels. For example, the deficiencies in the public infrastructure that defended the inflowing, channeled rivers in the surroundings of the Doñana marshlands resulted in several floods characterized as disastrous that ravaged the impoldered lands and colonial towns from 1892 to 1916, and broke down new dikes built with private funding in 1927 (Enggass 1968). Dikes were however rebuilt, heightened, and reinforced in the entire area (e.g., by the Guadalquivir Marshes Company for rice cultivation) without apparent detectable revision of the underlying strategies (Enggass 1968, González-Arteaga 2005). Similarly, the projected economic targets for the production of irrigated lands (e.g., cultivation of cereals, commercial crops, and forage) were not met due to lack of 
adequate infrastructure for reducing soil salinity and draining regularly flooded farmland, compounded by the fragmentary planning and uncoordinated work (Enggass 1968). However, both these targets and the agronomic planning behind them remained uncontested (Enggass 1968, González-Arteaga 2005).

In other words, the recurrent impact of natural disasters and the low economic performance of the production systems did not challenge the existing, on-the-ground approaches for WRM, owing to the strong institutional support for the implementation of new technologies. Thus $\Omega$ phases were not followed by $\alpha$ phases of destructuration and renewal. These phases are indicated as $\Omega$ ' to emphasize the absence of $\alpha$ phases (Fig. 3, point 5), and the reestablishment of the $\mathrm{K}$ phase after them (Fig. 3, point 6). This whole period followed the collapse of the Ancient Regime and coincided with the Spanish Liberal Reform (1833-1870s) and Liberal-State Consolidation (1870s-1920s) periods (see Appendix 1). It can be conceptualized as a broad critical juncture (CJ1; see Fig. 3), characterized by incremental change and the quasi-sequential accumulation of institutional events depicted in Table 3.

The regime-level processes described so far suffered an almost complete collapse (depicted again as a $\Omega$ ' phase; Fig. 3, point 7) during the Civil War but, immediately after it, recovered momentum swiftly and returned to the pre-existing $\mathrm{K}$ phase (Fig. 3, point 7). This phase became further stabilized by a diverse set of reinforcements at the constitutional level, underpinned by institutional legacies from the past that persisted at different levels. For example, during the 1940s, the regime gradually shifted from being based on communal lands and public property, to a mixed public-private system led and controlled by the engineers of the new authoritarian government, who promoted further the drainage-canalizationcolonization strategy established during the previous decades. Furthermore, in 1944, the Guadalquivir River Authority (a State organization created in 1927) presented for the first time a coordinated plan for the canalization and drainage of the Guadiamar River, aimed at halting its discharge into the Doñana marshes. The project had been backed by pre-war institutions (e.g., Gasset Act of 1911) and benefited, at this later time, from the development of existing infrastructure.

The post-war regime thus resumed the intensive exploitation of the region, and expanded its focus from agriculture and water resources into forest resource policies and institutions, including the development of extensive eucalyptus afforestations aimed at providing raw materials for industry. The development of new drainage projects for agriculture was fuelled by the synergies from other economic sectors that participated in the development processes, the all-time records of the Spanish GDP during the late 1940s, and the nation-wide autarchy imposed by Franco, which emphasized national food security and supply self-sufficiency. In the 1960s and 1970s these developments, described by some authors as a land reclamation process (Engass 1968), favored the north-to-south colonization of the Guadalquivir River's right bank territories, including about 2/3 of the Doñana marshes.

Table 3. Main institutional events characterizing CJ1.

1. Inherited, inter-scale institutional void between nobility elites and local administrations.

2. Establishment of the bases for the development of local and foreign trade, by enhancing, for example, navigation in the Guadalquivir River.

3. Diversification of, and increase in, the productivity of communal lands (e.g., establishment of pine tree plantations for the production of energy, construction material, and coal).

4. Allocation of exchange value, mainly to Guadalquivir River's left bank marshlands (e.g., creation of farmland and related industry around municipal entities).

5. Provision to wealthy, middle-class private actors (r-strategists) of easy access to title deeds of indivisible properties (large estates) and smallholdings, favoring large investments of capital for land purchase and the establishment of a nascent middle class (economic policies for Liberal-State consolidation).

6. Settlement of the contemporary public debt of the Government Treasury (tax policies).

7. Implementation of new public infrastructure and innovative engineering technologies aimed at intensifying production and maximizing returns.

8. Spanish economy leaving behind a period of decline. All-time records of the GDP during the 1920s.

In summary, in the period comprised between the 1920s and the 1960s, the institutional regime for WRM increased its resilience owing to the maintenance of the former production and engineering schemes, the changes in the property system, and the increasing interventionism and bureaucratization of the State. The regime became fully stabilized in a $\mathrm{K}$ phase dominated by K-strategists (Fig. 3, point 7).

\section{Wetland conservation}

Spain's institutional regime for nature conservation probably has its foundational constitutional event in the passing of the National Parks Act of 1916. Among the various models of conservation available at the time, governmental authorities selected the top-down implementation of a National Parks system. New room emerged for pioneers to fulfill the institutional developments demanded by the new conservation paradigms. An entirely new institutional regime for nature 
conservation was purposely created and connectedness among officials and pioneer entrepreneurial actors began to increase. During a short, $\alpha$-r phase (Fig. 3, point 8 ) new organizational structures were created and empowered to operate at the national level, taking elements and techniques from the conservation regimes of other Western countries (such as the USA), but necessarily subservient to the powerful forestryand civil-engineering corps, which systematically excluded from protection "unproductive lands", i.e., marshland/ wetland ecosystems. The incipient institutional regime for nature conservation became rapidly dominated by policies and operational techniques already in place for the exploitation of forests, game, and fish.

Although the Spanish Civil War halted the development of nature conservation policies ( $\Omega$ ' phase; Fig. 3, point 7 ), the tandem National Parks/ Forestry Policy persisted after it as the preferred operational model at the national level. Following the top-down, constitutional implementation of new institutions (e.g., Forestry Heritage Act of 1941, Forestry Act of 1957), the regime for nature conservation and forest resource management became increasingly bureaucratic and rigid, and focused almost exclusively on maximizing economic returns. Hence, it rapidly entered a K phase (Fig. 3, point 9).

In spite of the strong rigidity characteristic of K-phase institutional configurations, small crises and reorganization may be triggered by groups of actors, self-organized in coalition networks, which benefit from "windows of opportunity" to introduce novelty (i.e., small $\Omega$ - $\alpha$ phases triggered by $\Omega$ - $\alpha$ groups; Gunderson et al. 1995, Olsson et al. 2006). This was the case in Doñana. During the 1950s and the 1960s, perhaps due to its early establishment as one of the most important waterfowl reserves in Europe at the end of the $19^{\text {th }}$ century, a growing awareness of the necessity to safeguard the conservation of its marshland/ wetland ecosystems built up, at both national and international levels.

A careful analysis of historical events shows that, in parallel to the development of the institutional regime for nature conservation, a small $\Omega-\alpha$ group of actors from the scientific sector (e.g., J. A. Valverde, F. Bernis), informally organized at the operational level, became aware of the unstoppable degradation of Doñana's marshland/ wetland ecosystem and started an effective lobbying campaign to introduce a new set of protection policies for their conservation (Fig. 3). These policies were not the result of a strategic analysis and decision making in the public policy sector, but the work of a network of private pioneers and strategists who raised ecological awareness at the societal level and triggered new policy formulations (Valverde 2004).

A $\Omega-\alpha$ group that succeeds in achieving change and introducing novelty often benefits from key reinforcements by powerful external groups (Gunderson et al. 1995). In
Doñana, several international organizations supported the $\Omega$ $\alpha$ group with key knowledge and funding (e.g., the International Union for Conservation of Nature, IUCN, and the International Waterfowl and Wetlands Research Bureau, IWRB). The lobbying and fundraising campaign reached a peak with the constitution of the World Wildlife Fund for Nature (WWF), the acquisition of large areas of marshland and surrounding forests, and the creation of the Doñana Biological Reserve and Doñana Biological Station (Fernández and Pradas 2000b, Valverde 2004). Indeed, the creation of the WWF was an unexpected international repercussion of the local, protection-for-conservation struggle. The Doñana Biological Station received the constitutional mandate of conducting research and managing the Doñana Biological Reserve, and a sizable portion of the original marshland and dunes were included in the new Doñana National Park (Act of 1969).

\section{From 1970 to 2000}

During the 1970s, both regimes entered a new phase, during which novel $\alpha$-type attempts to harmonize WRM and WC took place. In 1978, after the constitutional replacement of Franco's authoritarian government by a democratic one, the new Doñana National Park Act of 1978 (hereafter Doñana Act) established novel operational guidelines for conservation inside and outside the park, demonstrating for the first time, de jure, the public interest in the conservation of its aquatic ecosystems. The new institution seemingly laid the foundations for the consolidation of the WC regime and the collapse of the old WRM regime. However, the old technocratic organizations, paradigms, and institutions maintained their top-down, command-and-control approaches and their focus on engineering works. Thus, the institutional regime for WC entered, after this short period (which can be characterized as a failed $\Omega^{\prime}$ - $\alpha$ phase, Fig. 3, point 10 ), a stable $\mathrm{K}$ phase in close synchrony with the WRM regime (Fig. 3, point 11).

In our view, this was due to three main mechanisms that coincided with another critical juncture (CJ2; see Fig. 3) during the 1960-1970 period of progressivism and transition to democracy (see Appendix 1). Firstly, the management-forconservation institutions and organizational structures were co-opted by the old-fashioned engineering lobby, which dominated the public sector and still endorsed the previous management-for-productivity, command-and-control framework. During the 1960s, the Forestry Directorate lived a struggle of power between pro-conservation engineers and old-school ones, focused exclusively on economic productivity (Fernández and Pradas 2000a). Pro-conservation engineers received the support of the Doñana Biological Station, but the struggle was dominated by the established, old-school engineering lobby by 1971, when the Forestry Directorate and the Forestry Heritage merged to become the Nature Conservation Institute (ICONA; Fernández and Pradas 
Fig. 4. Evolution of Doñana's hydraulic system between 1900 and 2000.
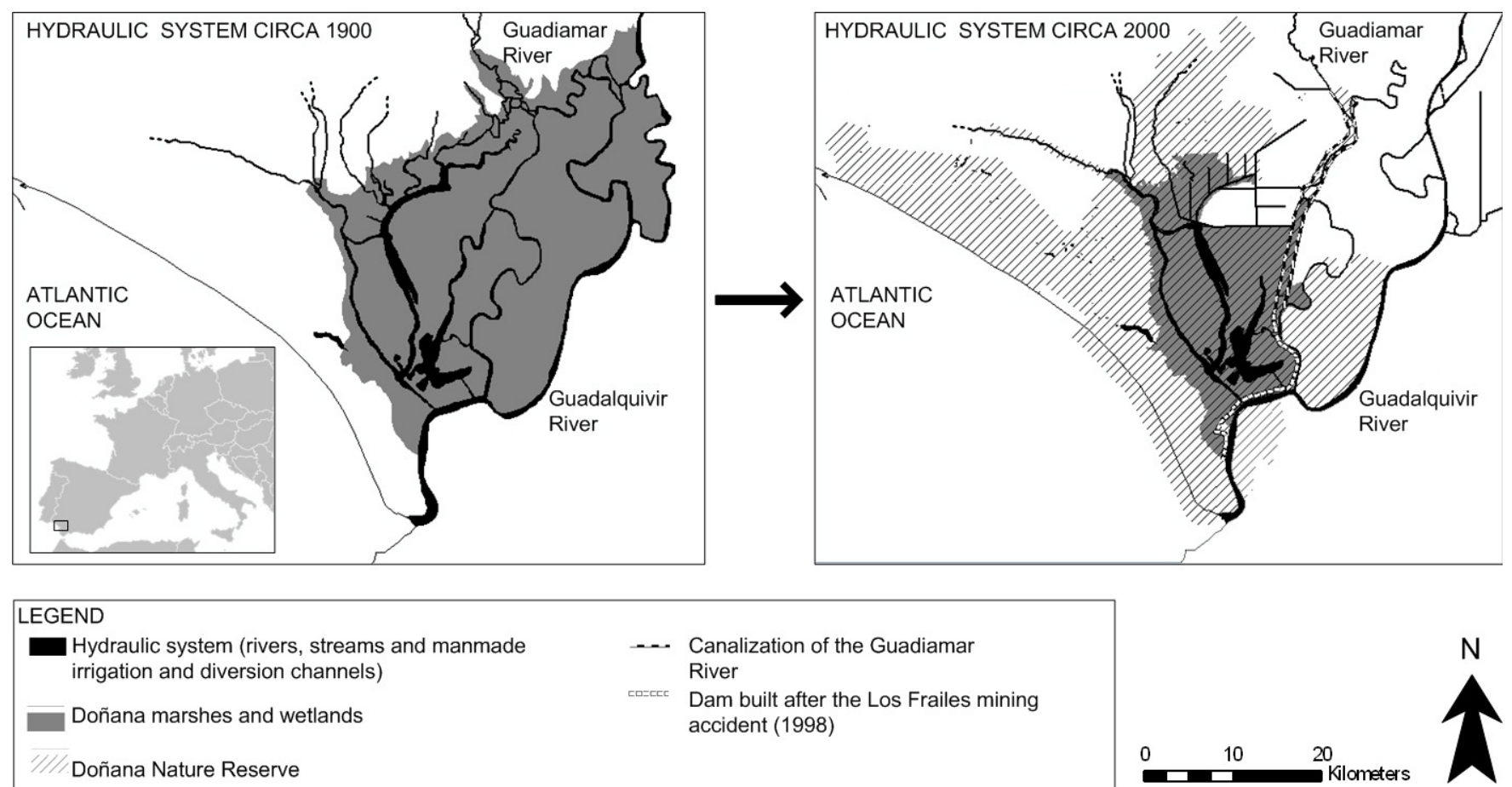

$$
\begin{aligned}
& \text { Canalization of the Guadiamar } \\
& \text { River } \\
& \text { Dam built after the Los Frailes mining } \\
& \text { accident (1998) }
\end{aligned}
$$

2000a). By 1974, J. A. Valverde, the most significant champion of the Doñana's protection-for-conservation race, was replaced by an old-school engineer as director of the National Park (Valverde 2004).

Secondly, the Doñana Act consolidated the dominance of the engineering lobby in the management of the National Park. The direction of the National Park and the Biological Reserve were respectively assigned to the ICONA (Ministry of Agriculture) and the Doñana Biological Station (Spanish Research Council, Ministry of Education). Both agencies received separate mandates: ICONA should manage the Park, while the Doñana Biological Station should guarantee scientific research and monitor its conservation. The conservation of the Doñana marshes, therefore, became dependent on the institutional relationships between the Doñana Biological Station and the ICONA, which personalized the existing tensions among conservationists and old-school engineers (Valverde 2004).

Thirdly, this period was characterized by the promotion of intensive development in the immediate surroundings of the National Park, which was clearly at odds with its long-term purpose and objectives. Governmental agencies, supported by a blooming national economy, continued acquiring more territory, draining wetlands and marshes to gain agricultural lands (e.g., rice cultivation; González-Arteaga 2005), and developing irrigation schemes to feed them with both surface and groundwater. As a consequence, the last strides of pristine marshes in the immediate vicinity of the recently created National Park were transformed; the hydraulic system that fed the Park's marshes was drained, diverted, controlled, or canalized; and the Doñana marshes became progressively dependent on a completely artificial water management regime, which has lasted until today (Figure 4).

During the 1980s and the 1990s, the synchronized K-phase regimes proved their ever-increasing institutional resilience by surviving several $\Omega$-type crises (Fig. 3, point 12), including:

- the operational crisis caused, in the late 1980s, by the defective design of the Doñana Hydraulic Regeneration Plan, which failed to restore the intended water inflows and left behind inefficient infrastructure (e.g., channels, sluices; Casas and Urdiales 1995);

- the ecological, operational and political crisis caused by the recurrence of massive waterfowl mortalities, during the early and mid 1980s ("botulism crises", Amezaga and Santamaría 2000, Fernández-Delgado 2006);

- the ecological, operational and political crisis caused, in 1998, by the accident at Los Frailes metalliferous mine, which contaminated the Guadiamar River and the Doñana Natural and National Parks (Grimalt et al. 1999, García and Marín 2006). 
None of these crises resulted in the introduction of significant innovative changes within the regimes, at any institutional level. Paradoxically, they resulted instead in the reinforcement of command-and-control approaches, the increase of the regimes' institutional resilience and their recursive recycling in a permanent $\Omega^{\prime}$-K phase (Fig. 3, point 13) that increased further the risk of new social-ecological collapses.

On the basis of our historical interpretations, we argue that the developments of the outcome regimes during the last decades of the $20^{\text {th }}$ century can be characterized by:

- high stability;

- top-down, hierarchical decision making and passive public participation processes;

- reduced opportunity for innovation;

- highly bureaucratized, rigid, atomized, and internallyfocused organizations in which power distance has been promoted;

- an intensively modified hydraulic system sprinkled with inefficient infrastructure;

- a contest of perspectives about the perceived problems, spinning tightly around an economic development vs. nature conservation dichotomy (see also Palomo et al. 2011);

- a highly subsidized economy, based on a few agricultural options (e.g., rice and strawberry cultivation) and continuously threatened by both endogenous (e.g., water shortages) and exogenous factors (e.g., market drift) (González-Arteaga 2005).

Especially relevant is the current hydraulic regime of the remaining marshland/wetland ecosystems protected within the current Doñana Nature Reserve, which largely depends upon artificial management (Fig. 4). For example, water is controlled via a surrounding clay dam equipped with outflow channels and sluice gates, and the flooding regime is halted by early June to prevent waterfowl mortalities triggered by botulism (Casas and Urdiales 1995, Clemente et al. 2004, García and Marín 2006).

\section{From 2000 to 2008}

During the first decade of the $21^{\text {st }}$ century, the institutional regimes for WRM and WC have been fundamentally influenced by the public shock caused, in 1998, by the previously mentioned Los Frailes mining accident. This accident provided impetus for the application of two hydroecological restoration projects, implemented separately by the regional ("Guadiamar's Green Corridor", 1998-2002; Montes 2002) and national ("Doñana 2005", 1998-2006; García and Marín 2006) Ministries of Environment. In both cases, the projects explicitly acknowledged the need for new alliances between science and management, and opened a window of opportunity for the promotion of new institutional configurations. There was enough flexibility for enrolling a wide range of stakeholders and developing new forms of participation and management at the operational levels (e.g., adaptive management, participatory action research; see G. K. Meffe, T. Dunne, and J. B. Zedler 2002, unpublished report, Montes 2002, Arenas et al. 2003, Escalera 2003, Santamaría et al. 2006). However, the inertia of the former institutional regime progressively compromised these initiatives and, after a period of creativity largely restricted to the declarative phase, both projects returned to top-down models of organization and implementation, largely based on the endorsement of civil engineering-based works (see, e.g., the post-implementation views reported in Arenas 2003 and Arenas and Carrascal 2004, in which references to adaptive and participatory approaches are conspicuously absent, or the specific restoration works reported in García and Marín 2006).

\section{DISCUSSION}

\section{h1 evaluation: implications for theory}

Our analytical interpretation indicated that, if theories based on the efficiency and productivity baseline are used (e.g., neoclassical economic theory), $h_{l}$ can be validated. Our data show, indeed, that the current RIR (i.e., institutional outcome) is characterized by system-wide (institutional, organizational, and epistemological) inefficiency in its current societal function, which requires the integration of economic development, water resource management (WRM), and wetland conservation (WC) goals. The RIR is not, therefore, a necessary or expected outcome of the institutional events that occurred during the first critical juncture (CJ1), during which the implementation of command-and-control approaches responded to a search for economic efficiency and productivity.

If novel frameworks, based upon resilience and adaptive change disciplines, are used, $h_{l}$ can also be validated. However, its evaluation requires the inclusion of an additional conceptual layer to our theoretical framework, hence a more elaborated argumentation. Our analytical interpretations support the characterization of Doñana's RIR as path dependent. The institutional regime for WRM once fit the adaptive cycle, between the end of the $18^{\text {th }}$ century and the outset of the $19^{\text {th }}$. Based on our theoretical framework, this was logically expected and predicted to occur, therefore, it represented a path independent event. However, from that moment to the present, the institutional regime for WRM twirled recurrently in a persistent $\Omega^{\prime}-\mathrm{K}$ phase; and the emerging WC regime was quickly synchronized to this dynamic. This recurrence cannot be predicted by the adaptive cycle theory, at least in its simplest form. But, was it completely unpredictable?

If we consider, in retrospective, the theory on maladaptive traps that departs from the adaptive cycle (Holling et al. 2002), 
the establishment of a RIR is theoretically probable. Indeed, a RIR fits the features of a rigidity trap fairly well, e.g., a high potential for change, connectedness, and resilience (see Allison and Hobbs 2004). But the existence of a probable outcome does not necessarily imply that it is a predictable consequence of a given set of conditions. In Doñana, the institutional regime for WRM could have stabilized following $\mathrm{CJ} 1$ around three feasible alternative configurations, namely: (1) an adaptive regime that completed, at least, a second adaptive cycle, (2) the chaos trap (high potential, but low connectedness and resilience; Loring 2007), and (3) the lockin trap (low potential, but high connectedness and resilience; Allison and Hobbs 2004).

In the first case, the inference is straightforward: actors learn, after the $\Omega$ '-type crises, the long-term inefficiencies of command-and-control approaches and, instead of promoting institutional reproduction, they foster institutional innovation and restructuring on the basis of the lessons learnt (i.e., $\alpha$ phases). In the second case, certain constraints (e.g., the nonexistence of public funding, such as in the period prior to $\mathrm{CJ} 1$ ) deprive command-and-control approaches of their initial advantages, which results in a backlash or breakdown of the institutional regime (sensu Brugge and Rotmans 2007) and its return to a previous configuration, based for example on a structurally weak and low-resilient, self-sustainable economy (which fits the features of the chaos trap; see Loring 2007). In the third case, the regime enters a path in which the whole ecological system becomes irreversibly modified for economic productive purposes, losing its most important ecological and hydraulic components, and posing high sunk costs (i.e., it enters a lock-in trap; see Allison and Hobbs 2004).

Our interpretations show that none of these alternatives crystallized. Instead, the regime stabilized around a rigidity trap, foreseen by theory but unpredictable on the basis of the preceding events, making the outcome path dependent. During CJ1, several alternative configurations, especially the lock-in trap, seemed to be equally probable; it was only after CJ1 that the regime began to stabilize around the rigidity trap. We now turn to a discussion of why.

\section{Historical mechanisms underlying institutional rigidity}

After CJ1, the winning institutional configuration was one imbued with institutional arrangements based upon commandand-control approaches for WRM at the estuary level. These arrangements, focused on economic/ organizational efficiency and the maximization of productivity, appeared to have competitive advantages over alternative approaches (e.g., selfsufficient economies based on traditional ecological knowledge). They capitalized on their advantages during the early periods of the juncture and became locked in within the institutional regime in posterior periods.
In our view, the lock-in of command-and-control at the operational levels was facilitated by several self-enforcing events, characterized by "increasing-returns" mechanisms and favored by past structural flaws (e.g., initial inter-scale institutional void). These mechanisms operated before and during the 1920s, despite the verified inefficiency of the approach ( $\Omega$ '-type crises). The most clear example involves the actors' expectations about the returns on investments in innovative technologies, agricultural development, and engineering works supported by public funding. Incremental investments in public and private infrastructure led to large set-up costs that created, in turn, increasing payoffs for further investments in infrastructure and transformative technologies. As they gained experience and knowledge from the recursive operation over the hydro-ecological system, actors were affected by learning and coordination effects, and benefited increasingly from the extension of command-and-control approaches to water resource management and marshland/ wetland transformation (i.e., actors were r-strategists).

In this way, the winning institutional configuration entered a developmental path characterized by the top-down reproduction of institutions aimed at reinforcing the array of command-and-control approaches developed at the operational level. Such institutions sought to recoup costs and incentivize the streamlined operation of the existing structures. In fact, they reinforced the on-the-ground investments for the transformation of Doñana's hydro-ecological systems into productive lands and waters, as well as their intensive exploitation.

The persistence of such institutional configuration during all subsequent periods, despite the existence of several windows of opportunity for the promotion of new institutional configurations (e.g., $\Omega$ - $\alpha$ group action, Doñana Act of 1978) and more $\Omega$ '-type crises, was rooted in its strong inertia and the power of technocratic elites (i.e., K-strategists). Such elites legitimated and supported, from the constitutional level and through institutional reproduction mechanisms, an inherent institutional logic that curtailed reorganization and renewal. This was done, for example, by changing the property system, increasing interventionism and bureaucratization at all levels, or replacing local change champions. In other words, the institutional events that took place prior (Autarchic period) and during CJ2 reinforced the system's path dependence, and the trajectory of the Doñana's WSES entered a pathological rigidity trap characterized by high potential for change, high connectedness, and high resilience.

Why not a low-potential lock-in trap? Firstly because, contrary to other regions where lock-in traps have been described (Allison and Hobbs 2004), the Doñana WSES has retained part of its wetland/ marshland ecosystems isolated in a Nature Reserve, owing to the innovative action of the $\Omega$ - $\alpha$ group during the 1950-60s. In other words, it has retained a sizable 
part of its structural and natural capital. Secondly, because the window of opportunity opened after the Los Frailes mining accident allowed the proactive introduction, by several independent actors, of bits of innovation within the regime (for example, promotion of novel, learning-by-doing and participatory approaches for hydro-ecological restoration; Escalera 2003, Santamaría et al. 2006). In our opinion, these two factors leave sufficient scope and opportunities for the development of a flexible and adaptive institutional regime, more independent of historical factors and better suited to return Doñana's WSES to a more healthy and sustainable state.

\section{Preliminary insights from the action-research program}

The results of the historical analysis informed the design of our action-research program, which we regarded as an indispensable step for a transition toward more flexible and adaptive regimes over the long term. The program was tailored to: (1) generate networking and build trust among the various, disconnected, often competing agencies in charge of WRM and WC, and (2) to inform the development of small-scale, successful examples of adaptive management at the operational level (Santamaría et al. 2006). In particular, the use of an action-research approach allowed us to introduce new modes of actor involvement (actor analysis and interviews) and promote a collaborative understanding of the challenges facing Doñana's WRM and WC (workshops). We will now provide a number of preliminary insights derived from it, with an emphasis on the research management workshop that culminated it (see Appendix 2 for a detailed description of the specific methods used in the program, which took place from 2006 to 2008). A complete analysis of the interviews (e.g., trust evaluation, management narratives), current policy and legislation will be presented elsewhere.

Our historical analysis indicated that Doñana's institutional regimes for WRM and WC developed, over time, disparate strategies that deepened the conflict between water resource management and wetland/ marshland conservation. This problem was formalized and discussed at the research management workshop. The workshop revealed that the different actors held contrasting mental models about WRM and WC, which included different perceptions about nature (nature in static equilibrium vs. constantly evolving nature) or about the procedures for making decisions (hierarchically vs. collectively). During the sessions, facilitated through Group Model Building, these differences were made explicit, collectively discussed and accommodated in shared models. Participants were organized in two thematic groups (water and vegetation) and requested to identify first-order and secondorder drivers of change towards the accomplishment of a main goal, involving, in both cases, sustainable performance (Table A2.4; output models are provided in Figs. A2.2 and A2.3). Sources of uncertainty were subsequently identified; they included gaps in ecological and socioeconomic knowledge, complex ecosystem behavior, unpredictable reactions of society to management decisions, unexpected political developments (such as changes in EU policies), and climate change. Uncertainties were then scored for importance and urgency. Climate change was scored as the "most worrying" source of uncertainty in both sessions; however, it was not considered the most urgent. Instead, participants assigned the highest priority to actions addressing: (1) the lack of knowledge about the hydrological system, and (2) the unpredictable reactions of society to management decisions.

A preliminary analysis of the interviews and workshops led us to the realization that their combined use constituted a powerful tool to identify and develop, informally and collectively, unexpressed ideas that had remained tacit but were broadly accepted (e.g., the existence of large power differences between individuals within management agencies, expressed by most actors from the operational levels). The combined use of thematic talks, facilitated discussion, and Group Model Building proved also to be instrumental for the participatory identification of future steps and initiatives toward institutional change (summarized in Table 4). Finally, it is worth noting that action-research initiatives represent a demanding task requiring updated knowledge about the case study, in situ social capital, strong commitment, resilience to short-term failure, and considerable social/ emotional skills, particularly since those involved in them usually enter a locked conflict as "external insiders" (see Appendix 2), and must navigate the risk of being involuntarily involved in the conflict themselves.

\section{GROUNDED SPECULATION AND FURTHER RESEARCH NEEDS}

Our historical analysis and the preliminary insights from the action-research program suggest that the statutory backing of the European Water Framework Directive (WFD) could provide the momentum needed for an innovative change in Doñana's WSES. For example, one of the conclusions of the management workshop was the need to draw specific plans for the wider catchment area influencing the Doñana Nature Reserve, complemented by the separate delimitation of the subbasin (with a specific management plan) directly influencing the Doñana wetlands. Article 13.5 of the WFD states that River Basin Management Plans may be supplemented by the production of more detailed programs and management plans for sub-basins, to deal with particular aspects of water management. The directive also requires special attention for protected areas, which have to be registered (Article 6 and Annex IV) and covered by adequate monitoring programs (Article 8).

Furthermore, participatory processes similar to those of our action-research program could become the cornerstone of the process of public information and consultation required by Article 14, in the spirit of the widening participation proposed by the WFD guidelines (WFD Common Implementation 
Strategy 2003). Our reasoning could be generalized to comparable cases, in which key protected nature reserves including wetlands are important elements of a river basin. Such participatory processes could provide both a solid interface with a whole range of stakeholders, and a platform for the dynamic interaction between research and management.

Table 4. Shared list of recommendations to foster the improvement of the research-management interface in Doñana.

1. The transparent definition of shared management goals and functioning models of Doñana Nature Reserve's (DNR) marsh/ wetland ecosystems.

2. The structuring of existing monitoring programs, based on established goals and functioning models, and seeking to optimize coordination among agencies.

3. The incorporation of social research and public participation into policy making and management plans.

4. The definition, within the new Management Plan of the Guadalquivir River Basin, of a specific sub-basin for the DNR wetlands and its tributaries. Such a definition would resolve the contradiction inherent to the declaration of most river branches flowing into or surrounding the DNR as highly modified watercourses (therefore free from the obligation of achieving a good ecological status).

5. The continuation and enhancement of the collaborative dynamics that emerged after the Los Frailes mining accident. These dynamics are broadly perceived as a social good, which should be promoted both politically and economically.

6. The improvement of mechanisms for information exchange and inter-agency goal definition among the Doñana Nature Reserve, the Doñana Biological Station and the Guadalquivir River Authority. Examples include the development of protocols, standards, joint committees, virtual workspaces, and corporate databases for mutual support and joint decision making.

7. The stepwise introduction of learning, novelty, and innovation into management, based on the transfer of knowledge generated in well-defined pilot projects and programs.

In the Doñana case, future research aimed at guiding managed transitions must be based on collaborative analyses of the current institutional configuration at different levels, focusing, for example, on the role of culture, or the impact of current policies and legislation upon the management at operational levels. For this purpose, our theoretical framework could be best complemented by using updated versions of the IAD as a meta-conceptual framework (Poteete et al. 2010), cross-scale interrelationships (panarchy heuristic; Gunderson and Holling
2002) and managed transitions (transition arenas; Brugge and van Raak 2007). As a final note, we would like to stress the importance of continuing the micro-analyses of crossdisciplinary teams implementing action-research programs, a research topic that has been addressed in other recent articles (see e.g., Daniell et al. 2010, Huitema and Meijerink 2010, Moellenkamp et al. 2010).

\section{CONCLUSIONS}

The historical persistence of command-and-control approaches for water resource management and wetland conservation is a path dependent process that led to the emergence of a rigid institutional regime in the Doñana water socio-ecosystem, and caused it to enter a pathological stable state that can be characterized as a rigidity trap. Doñana still retains a high potential for change in the form of structural and natural capital, which opens considerable opportunities for managed transitions towards more flexible and adaptive institutional regimes. Our analysis shows how the heuristics posed by adaptive change theories, complemented with concepts borrowed from institutional theory, can be used to understand and describe the trajectory of institutional regimes, as well as to evaluate and generate theory, thus increasing our predictive power. Historical analyses such as the one presented here may serve the purpose of informing and guiding the design of action-research programs aimed at facilitating transitions in rigid institutional regimes.

Responses to this article can be read online at: http://www.ecologyandsociety.org/voll7/iss1/art26/ responses/

\section{Acknowledgments:}

We are particularly grateful to Glen Hearns for his contribution to the research-management workshop, as well as to all the interviewees and participants of the workshops carried out under the umbrella of this project who kindly provided time, data, experiences, results, and insights from their management experience and research projects. Critical comments from four anonymous reviewers, $K$. Daniell, $R$. Bijlsma, and F. J. Fernández Segura significantly improved earlier versions of the manuscript. Funding by the Doñana 2005 Project (Guadalquivir River Authority, Spanish Ministry of Environment), the Canada-Europe Awards (International Council for Canadian Studies, Government of Canada), and the NeWater Project (Contract no. 511179, 6th EU Framework Program) is also gratefully acknowledged.

\section{LITERATURE CITED}

Adger, W. N. 2000. Social and ecological resilience: are they related? Progress in Human Geography 2(3):347-364. http:// dx.doi.org/10.1191/030913200701540465 
Allison, H. E., and R. J. Hobbs. 2004. Resilience, adaptive capacity, and the "Lock-in Trap" of the Western Australian agricultural region. Ecology and Society 9(1):3. [online] URL: http://www.ecologyandsociety.org/vol9/iss1/art3/

Amezaga, J. M., and L. Santamaría. 2000. Wetland connectedness and policy fragmentation: steps towards a sustainable European wetland policy. Physics and Chemistry of the Earth, Part B: Hydrology, Oceans and Atmosphere 25 (7-8):635-640. http://dx.doi.org/10.1016/S1464-1909(00)00077-0

Anderies, J. M., M. A. Janssen, and E. Ostrom. 2004. A framework to analyze the robustness of social-ecological systems from an institutional perspective. Conservation Ecology 9(1):18. [online] URL: http://www.ecologyandsociety. org/vol9/iss1/art18

Andersen, D. F., G. P. Richardson, and J. A. M. Vennix. 1997. Group Model Building: adding more science to the craft. Systems Dynamics Review 13(2):187-201. http://dx.doi.org/1 0.1002/(SICI)1099-1727(199722)13:2<187::AID-SDR124>3.0. $\underline{\mathrm{CO} ; 2-\mathrm{O}}$

Andrés-Gallego, J, editor. 1981. Revolución y restauración 1868-1931. Historia general de España y América (XVI-1). RIALP, Madrid, España.

Arenas, J. M. 2003. Situación actual y propuestas para la mejora de la funcionalidad del corredor fluvial del Guadiamar. Pages 139-156 in M. R. García-Mora, editor. Conectividad ambiental: las áreas protegidas en la Cuenca Mediterránea. Junta de Andalucía, Sevilla. España.

Arenas, J. M., F. R. Martínez, A. Mora, C. Montes, and F. Borja, editors. 2003. Ciencia y restauración del río Guadiamar. Consejería de Medio Ambiente, Junta de Andalucía, España.

Arenas, J. M., and F. Carrascal. 2004. Situación medioambiental del Corredor Verde del Guadiamar 6 años después del vertido de Aznalcóllar. Ecosistemas 13(3):69-78. [online] URL: http://www.revistaecosistemas.net/articulo.asp? $\underline{\mathrm{Id}=57}$

Arrow, K., G. Daily, P. Dasgupta, S. Levin, K. G. Mäler, E. Maskin, D. Starrett, T. Sterner, and T. Tietenberg. 2000. Managing ecosystem resources. Environmental Science and Technology 34(8):1401-1406. http://dx.doi.org/10.1021/es990 $\underline{672 \mathrm{t}}$

Arthur, W. B. 1994. Increasing returns and path dependence in the economy. University of Michigan Press, Ann Arbor, Michigan, USA.

Arthur, W. B. 1999. Complexity and the economy. Science 284:107-109. http://dx.doi.org/10.1126/science.284.5411.107
Baral, N., M. J. Stern, and J. T. Heinen. 2010. Growth, collapse, and reorganization of the Annapurna Conservation Area, Nepal: an analysis of institutional resilience. Ecology and Society 15(3):10. [online] URL: http://www.ecologyands ociety.org/vol15/iss3/art10/

Beier, C., A. L. Lovecraft, and T. Chapin. 2009. Growth and collapse of a resource system: an adaptive cycle of change in public lands governance and forest management in Alaska. Ecology and Society 14(2):5. [online] URL: http://www.ecolo gyandsociety.org/vol14/iss2/art5/

Berkes, F., J. Colding, and C. Folke, editors. 2003. Navigating social-ecological systems: building resilience for complexity and change. Cambridge University Press, Cambridge, UK.

Borja, F., J. A. López, M. Martín, R. Mantecón, C. Mediavilla, P. del Olmo, M. Palancar, and R. Vives. 2001. Marco geográfico, geológico e hidrológico regional de la cuenca del Guadiamar. Boletín Geológico y Minero volumen especial: 13-34.

Brock, W. A., and S. R. Carpenter. 2007. Panaceas and diversification of environmental policy. Proceedings of the National Academy of Sciences 104(39):15206-15211. http://d x.doi.org/10.1073/pnas.0702096104

Brugge, R., and J. Rotmans. 2007. Towards transition management of European water resources. Water Resources Management 21(1):249-267. http://dx.doi.org/10.1007/s1126 9-006-9052-0

Brugge, R., and R. van Raak 2007. Facing the adaptive management challenge: insights from transition management. Ecology \& Society 12(2):33. [online] URL: http://www.ecolo gyandsociety.org/vol12/iss2/art33/

Brunner, R. D., T. D. Steelman, L. Coe-Juell, C. M. Cromley, C. M. Edwards, and D. W. Tucker. 2006. Adaptive governance: integrating science policy and decision making. Columbia University Press, New York, NY, USA. http://dx.d oi.org/10.1111/j.1468-0491.2006.00333 1.X

Bunce, M., L. Mee, L. Rodwell, and R. Gibb. 2009. Collapse and recovery in a remote small island - a tale of adaptive cycles or downward spirals? Global Environmental Change 19:213-226. http://dx.doi.org/10.1016/j.gloenvcha.2008.11.005

Campbell, J. L., and O. K. Pedersen, editors. 2001. The rise of neoliberalism and institutional analysis. Princeton University Press, Princeton, New Jersey, USA.

Carpenter, S., W. Brock, and P. Hanson. 1999. Ecological and social dynamics in simple models of ecosystem management. Conservation Ecology 3(2):4. [online] URL: http://www.con secol.org/vol3/iss2/art4/ 
Carpenter, S. R., and L. H. Gunderson. 2001. Coping with collapse: ecological and social dynamics in ecosystem management. BioScience 51(6):451-457.

Carpenter, S., B. Walker, J. M. Anderies, and N. Abel. 2001. From metaphor to measurement: resilience of what to what? Ecosystems 4(8):765-781. http://dx.doi.org/10.1007/s10021-0 01-0045-9

Casas, J., and C. Urdiales. 1995. Introducción a la gestión hidráulica de las marismas del Parque Nacional de Doñana (S. O. de España). Pages 165-189 in C. Montes, G. Oliver, F. Molina, and J. Cobos, editors. Bases ecológicas para la restauración de humedales en la cuenca mediterránea. Consejería de Medio Ambiente, Junta de Andalucía.

Clement, F. 2010. Analysing decentralised natural resource governance: proposition for a "politicised" institutional analysis and development framework. Policy Sciences 43:129-156. http://dx.doi.org/10.1007/s11077-009-9100-8

Clemente, L., L. García, J. L. Espinar, J. S. Cara, and A. Moreno. 2004. Las marismas del Parque Nacional de Doñana. Investigación y Ciencia 332:72-83.

Collier, R. B., and D. Collier. 1991. Shaping the political arena. Critical junctures, the labor movement, and regime dynamics in Latin America. Princeton University Press, Princeton, New Jersey, USA.

Cortázar, F., and J. M. Vesga. 1994. Breve historia de España. Alianza, Madrid, España.

Costanza, R., L. Wainger, C. Folke, and K. G. Mäler. 1993. Modeling complex ecological economic systems. BioScience 43(8):545-555. http://dx.doi.org/10.2307/1311949

Cruz, J. 1996. El mapa de la política de colonización en Andalucía. Investigaciones geográficas 16:21-34.

Cumming, G. S., and J. Collier. 2005. Change and identity in complex systems. Ecology and Society 10(1):29. [online] URL: http://www.ecologyandsociety.org/vol10/iss1/art29/

Daedlow, K., V. Beckmann, and R. Arlinghaus. 2011. Assessing an adaptive cycle in a social system under external pressure to change: the importance of intergroup relations in recreational fisheries governance. Ecology and Society 16 (2):3. [online] URL: http://www.ecologyandsociety.org/vol16/ iss $2 / \operatorname{art} 3 /$

Daniell, K. A., I. White, N. Ferrand, I. S. Ribarova, P. Coad, J.-E. Rougier, M. Hare, N. A. Jones, A. Popova, D. Rollin, P. Perez, and S. Burn. 2010. Co-engineering participatory water management processes: theory and insights from Australian and Bulgarian interventions. Ecology and Society 15(4):11. [online] URL: http://www.ecologyandsociety.org/vol15/iss4/ $\underline{\operatorname{art} 11 /}$
David, P. A. 2000. Path dependence, its critics and the quest for 'historical economics'. Pages 15-40 in P. Garrouste, and $\mathrm{S}$. Ioannides, editors. Evolution and path dependence in economic ideas: past and present. Edward Elgar Publishing, Cheltenham, UK.

Davis, J. A., and R. Froend. 1999. Loss and degradation of wetlands in southwestern Australia: underlying causes, consequences and solutions. Wetlands Ecology and Management 7(1-2):13-23. http://dx.doi.org/10.1023/A:1008 400404021

Demerson, P. 1976. Sanlúcar de Barrameda en la corriente de la Ilustración. Instituto de Estudios Gaditanos, Diputación Provincial, Cádiz, España.

Domínguez-Ortiz, A. 2000. España. Tres milenios de historia. Marcial Pons, Madrid, España.

Enggass, P. M. 1968. Land reclamation and resettlement in the Guadalquivir Delta. Las Marismas. Economic Geography 44:125-143. http://dx.doi.org/10.2307/143310

Escalera, J. 2003. Investigación participativa para el desarrollo sostenible en el Corredor Verde del río de Guadiamar. Pages 528-537 in J. M. Arenas, F. R. Martínez, A. Mora, C. Montes, and F. Borja, editors. Ciencia y restauración del río Guadiamar. Consejería de Medio Ambiente, Junta de Andalucía.

Fernández-Albertos, J., and D. Manzano. 2010. Democracia, instituciones y política económica: una introducción a la economía política. Alianza, Madrid, España.

Fernández, J., and R. Pradas. 2000a. Historia de los Parques Nacionales Españoles. La Administración Conservacionista (1896-2000). Tomo I. Organismo Autónomo de Parques Nacionales, Ministerio de Medio Ambiente, Madrid, España.

Fernández, J., and R. Pradas. 2000b. Historia de los Parques Nacionales Españoles. Doñana, Tablas de Daimiel, Cabrera y Cabañeros. Tomo IV. Organismo Autónomo de Parques Nacionales, Ministerio de Medio Ambiente, Madrid, España.

Fernández-Delgado, C. 2006. Conservation management of a European natural area: Doñana National Park, Spain. Pages 458-467 in M. J. Groom, G. K. Meffe, and C. R. Carroll, editors. Principles of conservation biology. Sinauer Associates, Sunderland, Massachusetts, USA.

Fischer-Kowalski, M., and J. Rotmans. 2009. Conceptualizing, observing, and influencing social-ecological transitions. Ecology and Society 14(2):3. [online] URL: http://www.ecolo gyandsociety.org/vol14/iss2/art3/

Folke, C. 2003. Freshwater for resilience: a shift in thinking. Philosophical Transactions of the Royal Society of London (B) 358:2027-2036. http://dx.doi.org/10.1098/rstb.2003.1385 
Folke C., T. Hahn, P. Olsson, and J. Norberg. 2005. Adaptive governance of social-ecological systems. Annual Review of Environment and Resources 30:441-473. http://dx.doi.org/10 .1146/annurev.energy.30.050504.144511

Folke C., L. Pritchard Jr., F. Berkes, J. Colding, and U. Svedin. 2007. The problem of fit between ecosystems and institutions: ten years later. Ecology and Society 12(1):30. [online] URL: http://www.ecologyandsociety.org/vol12/iss1/art30/

García, F., and C. Marín, editors. 2006. Doñana, water and biosphere. Doñana 2005 Project. Guadalquivir River Authority, Ministry of Environment, Madrid, España. [online] URL: http://www.imedea.csic.es/bc/ecoesp/publications/Donana\% 2520Water\%2520and\%2520Biosphere.pdf

García-Viñas, J. I., J. A. Mintégui, and J. C. Robredo. 2005. La Vegetación en la Marisma del Parque Nacional de Doñana en Relación con su Régimen Hidráulico. Organismo Autónomo de Parques Nacionales, Ministerio de Medio Ambiente, Madrid, España.

Gleick P. H. 2003. Global freshwater resources: soft-path solutions for the 21st century. Science 302(5650):1524-1528. http://dx.doi.org/10.1126/science.1089967

Gómez-Baggethun, E., and E. Kelemen. 2008. Linking institutional change and the flows of ecosystem services. Case studies in Spain and Hungary. Pages 118-145 in T. Kuvánková-Oravská, V. Chobotova, J. Jilkova, and P. Sauer, editors. Institutional analysis of sustainability problems. Slovak Academy of Sciences, Bratislava, Slovakia.

González-Arteaga, J. 2005. El arroz en las marismas del Guadalquivir. Evolución y problemática actual. Publicaciones de la Universidad de Sevilla, Sevilla, España.

Gregory, R., L. Failing, and P. Higgins. 2006. Adaptive management and environmental decision making: a case study application to water use planning. Ecological Economics 58:434-447. http://dx.doi.org/10.1016/j.ecolecon.2005.07.020

Grimalt, J. O., M. Ferrer, and E. Macpherson. 1999. The mine tailing accident in Aznalcóllar. The Science of the Total Environment 242:3-11. http://dx.doi.org/10.1016/S0048-9697 (99)00372-1

Guadalquivir River Authority. 2010. Guadalquivir River Authority, Ministry of Environment, Spanish Government. [online] URL: http://www.chguadalquivir.es/opencms/portalchg/ index.html [last accessed: September 1, 2011]

Gunderson, L. H. 1999. Resilience, flexibility and adaptive management - antidotes for spurious certitude? Conservation Ecology 3(1):7. [online] URL: http://www.consecol.org/vol3/ iss $1 /$ art7/
Gunderson, L. H., and C. S. Holling, editors. 2002. Panarchy: understanding transformations in human and natural systems. Island Press, Washington, USA.

Gunderson, L. H., C. S. Holling, and S. S. Light, editors. 1995. Barriers and bridges: to the renewal of ecosystems and institutions. Columbia University Press, New York, USA.

Gunderson, L. H., and S. S. Light. 2006. Adaptive management and adaptive governance in the Everglades ecosystem. Policy Sciences 39(4):323-334. http://dx.doi.org/1 $\underline{0.1007 / \mathrm{s} 11077-006-9027-2}$

Hacker, J. S. 1998. The historical logic of national health insurance: structure and sequence in the development of British, Canadian, and U.S. medical policy. Studies in American Political Development 12:57-130. http://dx.doi.org /10.1017/S0898588X98001308

Hall, P. A., and R. C. R. Taylor. 1996. Political science and the three new institutionalisms. Political Studies 44 (5):936-957.

Hare, M., and C. Pahl-Wostl. 2002. Stakeholder categorisation in participatory integrated assessment processes. Integrated Assessment 3(1):50-62. http://dx.doi.org/10.1076/iaij.3.1.50.7408

Holling, C. S. 1973. Resilience and stability of ecological systems. Annual Review of Ecology and Systematics 4:1-23. http://dx.doi.org/10.1146/annurev.es.04.110173.000245

Holling, C. S. 1978. Adaptive environmental assessment and management. John Wiley \& Sons, New York, USA.

Holling, C. S. 1986. Resilience of ecosystems; local surprise and global change. Pages 292-317 in W. C. Clark, and R. E. Munn, editors. Sustainable development of the biosphere. Cambridge University Press, Cambridge, UK.

Holling, C. S. 1996. Engineering resilience versus ecological resilience. Pages 31-44 in P. Schulze, editor. Engineering within ecological constraints. National Academy, Washington, D.C., USA.

Holling, C. S., and C. R. Allen. 2002. Adaptive inference for distinguishing credible from incredible patterns in nature. Ecosystems 5(4):319-328.

Holling, C. S., and L. H. Gunderson. 2002. Resilience and adaptive cycles. Pages 25-62 in L. H. Gunderson, and C. S. Holling, editors. 2002. Panarchy: understanding transformations in human and natural systems. Island Press, Washington, D. C., USA.

Holling, C. S., L. H. Gunderson, and G. D. Peterson. 2002. Sustainability and panarchies. Pages 63-102 in L. H. Gunderson, and C. S. Holling, editors. 2002. Panarchy: 
understanding transformations in human and natural systems. Island Press, Washington, D. C., USA.

Holling, C. S., and G. K. Meffe. 1996. Command and control and the pathology of natural resource management. Conservation Biology 10(2):328-337. http://dx.doi.org/10.1046/ j.1523-1739.1996.10020328.x

Hotimsky, S., R. Cobb, and A. Bond. 2006. Contracts or scripts? A critical review of the application of institutional theories to the study of environmental change. Ecology and Society 11(1):41. [online] URL: http://www.ecologyandsociety. org/vol11/iss1/art41/

Hsieh, H. F., and S. E. Shannon. 2005. Three approaches to qualitative content analysis. Qualitative Health Research 15 (9):1277-1288. http://dx.doi.org/10.1177/1049732305276687

Huitema, D., and S. Meijerink. 2010. Realizing water transitions: the role of policy entrepreneurs in water policy change. Ecology and Society 15(2):26. [online] URL: http://w ww.ecologyandsociety.org/vol15/iss2/art26/

Ikenberry, G. J. 1994. History's heavy hand: institutions and the politics of the state. Presented at the Conference on The New Institutionalism. University of Maryland, October 14-15, 1994.

Isendahl, N., A. Dewulf, and C. Pahl-Wostl. 2010. Making framing of uncertainty in water management practice explicit by using a participant-structured approach. Journal of Environmental Management 91(4):844-851. http://dx.doi.org /10.1016/j.jenvman.2009.10.016

Janssen, M. A., J. M. Anderies, and E. Ostrom. 2007. Robustness of social-ecological systems to spatial and temporal variability. Society and Natural Resources 20 (4):307-322. http://dx.doi.org/10.1080/08941920601161320

Layder, D. 1998. Sociological practice: linking theory and social research. Sage, Guildford, UK.

Lee, K. N. 1993. Compass and gyroscope: integrating science and politics in the environment. Island Press, Washington, D. C., USA.

Lee, K. N. 1999. Appraising adaptive management. Conservation Ecology 3(2):3. [online] URL: http://www.con secol.org/vol3/iss2/art3/

Lee, K. N. 2003. Adaptive management in the Canadian Nuclear Waste Program. Nuclear Waste Management Organization, Background Papers. [online] URL: http://www. crcresearch.org/files-crcresearch/File/lee adaptive management. pdf

Levin, S. A. 1998. Ecosystems and the biosphere as complex adaptive systems. Ecosystems 1:431-436. http://dx.doi.org/10 $.1007 / \mathrm{s} 100219900037$
Llamas, M. R. 1988. Conflicts between wetland conservation and groundwater exploitation: two case histories in Spain. Environmental Geology and Water Sciences 11(3):241-251. http://dx.doi.org/10.1007/BF02574814

Loring, P. A. 2007. The most resilient show on earth: the circus as a model for viewing identity, change, and chaos. Ecology and Society 12(1): 9. [online] URL: http://www.ecologyands ociety.org/vol12/iss1/art9/

Mahoney, J. 2000. Path dependence in historical sociology. Theory and Society 29(4):507-548. http://dx.doi.org/10.1023/ A:1007113830879

Mahoney, J., and K. Thelen, editors. 2010. Explaining institutional change: ambiguity, agency, and power. Cambridge University Press, Cambridge, UK.

Marmorek, D. R., D. C. E. Robinson, C. Murray, and L. Greig. 2006. Enabling adaptive forest management - final report. Prepared for the National Commission on Science for Sustainable Forestry by ESSA Technologies Ltd., Vancouver, BC, Canada. [online] URL: http://essa.com/wp-content/uploa ds/2011/03/NCSSF_Adaptive_Forest_Mgmt.pdf

Martín-López, B., M García-Llorente, I. Palomo, and C. Montes. 2011. The conservation against development paradigm in protected areas: valuation of ecosystem services in the Doñana social-ecological system (southwestern Spain). Ecological Economics 70:1481-1491. http://dx.doi.org/10.1016/ j.ecolecon.2011.03.009

McLain, R. J., and R. G. Lee. 1996. Adaptive management: promises and pitfalls. Environmental Management 20 (4):437-448. http://dx.doi.org/10.1007/BF01474647

Meharg, A. A., D. Osborn, D. J. Pain, A. Sánchez, and M. A. Naveso. 1999. Contamination of Doñana food-chains after the Aznalcóllar mine disaster. Environmental Pollution 105:387-90. http://dx.doi.org/10.1016/S0269-7491(99)00033-0

Meinzen-Dick, R. 2007. Beyond panaceas in water institutions. Proceedings of the National Academy of Sciences 104(39):15200-15205. http://dx.doi.org/10.1073/pnas.0702296104

Méndez, P. F., L. Santamaría, J. Amezaga, and G. Hearns. 2010. Adaptive strategies for natural resources and ecosystems management in Canada. Opportunities and constraints for implementation in Europe. Prepared for the International Council for Canadian Studies. [online] URL: http://www.ime dea.csic.es/bc/ecoesp/publications/TechPub_ICCS-CEA_ebook. pdf

Millennium Ecosystem Assessment (MEA). 2006. Millennium Ecosystem Assessment synthesis reports. [online] URL: http: //www.maweb.org/en/Synthesis.aspx

Moberg, F., and V. Galaz. 2005. Resilience: going from conventional to adaptive freshwater management for human 
and ecosystem compatibility. Swedish Water House Policy Brief Nr. 3. Stockhold International Water Institute, Sweden.

Moellenkamp, S., M. Lamers, C. Huesmann, S. Rotter, C. Pahl-Wostl, K. Speil, and W. Pohl. 2010. Informal participatory platforms for adaptive management. Insights into niche-finding, collaborative design and outcomes from a participatory process in the Rhine basin. Ecology and Society 15(4):41. [online] URL: http://www.ecologyandsociety.org/vol15/ iss $4 / \operatorname{art} 41 /$

Montes, C. 2002. Lecciones aprendidas en tres años de restauración de ecosistemas en el Corredor Verde del Guadiamar. Ecosistemas 11(1). [online] URL: http://www.re vistaecosistemas.net/pdfs/314.pdf

Montes, C., F. Borja, M. A. Bravo, and J. M. Moreira. 1998. Reconocimiento biofísico de espacios naturales protegidos. Doñana: una aproximación ecosistémica. Consejería de Medio Ambiente, Junta de Andalucía, Sevilla, España.

Moral-Ituarte, L. 1991. La obra hidráulica en la cuenca del Bajo Guadalquivir (siglos XVIII-XX). Gestión del agua y organización del territorio. Publicaciones de la Universidad de Sevilla, Sevilla, España.

Moreno, I. 1992. Desarrollo del capitalismo agrario y mercado de trabajo en Andalucía. Estudios regionales 31:19-29.

Mostert, E. 2006. Participation for sustainable water management. Pages 152-176 in C. Giupponi, A. Jakeman, D. Karssenberg, and M. P. Hare, editors. Sustainable management of water resources: an integrated approach. Edward Elgar, UK.

Noble, B. F. 2000. Strengthening EIA through adaptive management: a systems perspective. Environmental Impact Assessment Review 20(1):97-111. http://dx.doi.org/10.1016/S 0195-9255(99)00038-4

Norberg, J., and G. S. Cumming, editors. 2008. Complexity theory for a sustainable future. Columbia University Press, New York, New York, USA.

North, D. C. 1990a. Institutions and their consequences for economic performance. Pages 383-401 in K. S. Cook, and M. Levi, editors. The limits of rationality. Chicago University Press, Chicago, USA.

North, D. C. 1990b. Institutions, institutional change and economic performance. Cambridge University Press, Cambridge, UK.

Ojeda, J. F. 1992. Políticas forestales y medioambiente en Doñana y su entorno. Agricultura y Sociedad 65:303-357.

Ojeda, J. F., and L. Moral-Ituarte. 2004. Percepciones del agua y modelos de su gestión en las distintas fases de la configuración de Doñana. Investigaciones Geográficas $35: 25-44$.
Olsson, P., L. H. Gunderson, S. R. Carpenter, P. Ryan, L. Lebel, C. Folke, and C. S. Holling. 2006. Shooting the rapids: navigating transitions to adaptive governance of socialecological systems. Ecology and Society 11(1):18. [online] URL: http://www.ecologyandsociety.org/vol11/iss1/art18/

Orti, A. 1984. Política hidráulica y cuestión social: orígenes, etapas y significados del regeneracionismo hidráulico de Joaquín Costa. Agricultura y Sociedad 32:11-107 [online] URL: http://www.marm.es/ministerio/pags/biblioteca/revistas/ pdf ays $\% 2 \mathrm{Fa} 032$ 01.pdf

Ostrom, E., R. Gardner, and J. Walker. 1994. Rules, games, and common-pool resources. The University of Michigan Press, Ann Arbor, Michigan, USA.

Ostrom, E. 2005. Understanding institutional diversity. Princeton University Press, New Jersey, USA.

Ostrom, E. 2009. A general framework for analyzing sustainability of social-ecological systems. Science 325 (5939):419-422. http://dx.doi.org/10.1126/science.1172133

Pahl-Wostl, C. 2007. Transitions towards adaptive management of water facing climate and global change. Water Resources Management 21:49-62. http://dx.doi.org/10.1007/s 11269-006-9040-4

Pahl-Wostl, C. 2009. A conceptual framework for analysing adaptive capacity and multi-level learning processes in resource governance regimes. Global Environmental Change 18:354-365. http://dx.doi.org/10.1016/j.gloenvcha.2009.06.001

Palomo, I., B. Martín-López, C. López-Santiago, and C. Montes. 2011. Participatory scenario planning for natural protected areas management under the ecosystem services framework: the Doñana social-ecological system, SW Spain. Ecology \& Society 16(1):23. [online] URL: http://www.ecolo gyandsociety.org/vol16/iss1/art23/

Perrings, C. 2006. Resilience and sustainable development. Environment and Development Economics 11:417-427. http:/ /dx.doi.org/10.1017/S1355770X06003020

Pierson, P. 1993. When effect becomes cause: policy feedback and political change. World Politics 45(4):595-628. http://dx. doi.org/10.2307/2950710

Pierson, P. 2000. Increasing returns, path dependence, and the study of politics. American Political Science Review 94 (2):251-267. http://dx.doi.org/10.2307/2586011

Polasky, S., S. R. Carpenter, C. Folke, and B. Keeler. 2011. Decision-making under great uncertainty: environmental management in an era of global change. Trends in Ecology and Evolution 26(8):398-404. http://dx.doi.org/10.1016/j.tree .2011 .04 .007 
Poteete, A. R., M. A. Janssen, and E. Ostrom. 2010. Working together: collective action, the commons, and multiple methods in practice. Princeton University Press, Princeton, New Jersey, USA.

Ramsar Convention Secretariat (RCS). 2006. The Ramsar Convention manual: a guide to the Convention on Wetlands (Ramsar, Iran, 1971). 4th edition. Ramsar Convention Secretariat, Gland, Switzerland.

Robson, C. 2002. Real world research. A resource for social scientists and practitioner-researchers. Blackwell Publishing, Oxford, UK.

Santamaría, L., and J. M. Amezaga. 1999. Improving the management of large protected wetlands: learning the lessons of the Doñana nature reserves. Pages 365-375 in C. A. Brebbia, and J. L. Usó, editors. Ecology and sustainable development II. WIT Press, Southhampton, UK.

Santamaría, L., A. Green, R. Díaz-Delgado, M. A. Bravo, and E. M. Castellanos. 2006. Caracoles - a new laboratory for science and wetland restoration. Pages 325-327 in F. García, and C. Marín, editors. Doñana, water and biosphere. Doñana 2005 Project. Guadalquivir River Authority, Ministry of Environment. [online] URL: http://www.imedea.csic.es/bc/ec oesp/publications/Donana\%2520Water\%2520and\%2520Biosphere. pdf

Santamaría, L., C. Montes, and M. J. M. Hootsmans. 1996. Influence of environmental parameters on the biomass development of Ruppia drepanensis populations in Doñana National Park: the importance of conditions affecting the underwater light climate. International Journal of Salt Lake Research 5:157-180. http://dx.doi.org/10.1007/BF01995828

Scheffer, M., S. R. Carpenter, J. Foley, C. Folke, and B. Walker. 2001. Catastrophic shifts in ecosystems. Nature 413:591-696. http://dx.doi.org/10.1038/35098000

Schumpeter, J. 1950. Capitalism, socialism and democracy. Harper and Row, New York, USA. http://dx.doi.org/10.4324 19780203202050

Smith, A., and A. Stirling. 2010. The politics of socialecological resilience and sustainable socio-technical transitions. Ecology and Society 15(1):11. [online] URL: http ://www.ecologyandsociety.org/vol15/iss1/art11/

Susman, G. I., and R. D. Evered. 1978. An assessment of the scientific merits of action research. Administrative Science Quarterly 23(4):582-603. http://dx.doi.org/10.2307/2392581

Tablado, Z., J. L. Tella, J. A. Sánchez-Zapata, and F. Hiraldo. 2010. The paradox of the long-term positive effects of a North American crayfish on a European community of predators. Conservation Biology 24(5):1230-1238. http://dx.doi.org/10. 1111/j.1523-1739.2010.01483.x
Taggart, M. A., M. Carlisle, D. J. Pain, R. Williams, D. Osborn, A. Joyson, and A. A. Meharg. 2004. The distribution of arsenic in soils affected by the Aznalcollar mine spill, Donana, SW Spain. Science of the Total Environment 323:137-152. http://d x.doi.org/10.1016/j.scitotenv.2003.10.008

Thelen, K. 1999. Historical institutionalism in comparative politics. Annual Review of Political Science 2:369-404. http:/ /dx.doi.org/10.1146/annurev.polisci.2.1.369

Tomás y Valiente, F. 1978. El proceso de desamortización de la tierra en España. Agricultura y Sociedad 1978:11-33. [online] URL:

http://www.mapa.es/ministerio/pags/biblioteca/revistas/pdf_ays/ a007 01.pdf

Vadineanu, A., and E. Preda. 2008. Watersheds management in Romania: challenges and opportunities. Pages 113-132 in I. E. Gönenç, A. Vadineanu, J. P. Wolflin, and R. C. Russo, editors. Sustainable use and development of watersheds. NATO Science for Peace and Security Series C: Environmental Security. http://dx.doi.org/10.1007/978-1-402 $\underline{0-8558-1 \_8}$

Valverde, J. A. 2004. La aventura de Doñana - Cómo crear una reserva. Quercus, Madrid, España.

Vennix, J. A. M. 1996. Group Model Building: facilitating team learning using system dynamics. John Wiley \& Sons, Chichester, UK.

Walker, B. H., C. S. Holling, S. R. Carpenter, and A. Kinzig. 2004. Resilience, adaptability and transformability in socialecological systems. Ecology and Society 9(2):5 [online] URL http://www.ecologyandsociety.org/vol9/iss2/art5/

Walker, B. H., and R. L. Lawson. 2006. Case studies in resilience: fifteen social-ecological systems across continents and societies. Appendix to the Ecology and Society Special Feature Exploring Resilience in Social-Ecological Systems. Resilience Alliance. [online] URL: http://www.resalliance.or g/1613.php

Walkerden, G. 2005. Adaptive management planning projects as conflict resolution processes. Ecology \& Society 11(1):48. [online] URL: http://www.ecologyandsociety.org/vol11/iss1/ $\underline{\operatorname{art} 48 /}$

Walters, C. 1986. Adaptive management of renewable resources (biological resource management). Blackburn Press, Caldwell, USA.

Walters, C. 1997. Challenges in adaptive management of riparian and coastal ecosystems. Conservation Ecology 1(2):1. [online] URL: http://www.consecol.org/vol1/iss2/art1/

Walters, C. J., and R. Hilborn. 1978. Ecological optimization and adaptive management. Annual Review of Ecology and Systematics 9:157-188. http://dx.doi.org/10.1146/annurev.es. $\underline{09.110178 .001105}$ 
WFD Common Implementation Strategy (CIS). 2003. Guidance Document No. 8. Public participation in relation to the Water Framework Directive. Published by the Directorate General Environment of the European Commission, Brussels, Belgium. [online] URL:

http://circa.europa.eu/Public/irc/env/wfd/library?l=/

framework directive/guidance documents/guidancesnos8spublicspar/ EN $1.0 \& \mathrm{a}=\mathrm{d}$

Yin, R. K. 2008. Case study research: design and methods. 4th edition. SAGE, California, USA.

Zedler, J. B., and S. Kercher. 2005. Wetland resources: status, trends, ecosystem services, and restorability. Annual Review of Environment and Resources 30:39-74. http://dx.doi.org/10 $.1146 /$ annurev.energy.30.050504.144248

Zouwen, M. 2006. Dynamics in nature policy practices across the European Union. Environment \& Policy 47:139-159. http ://dx.doi.org/10.1007/1-4020-5079-8 7 
APPENDIX 1. Resultant matrix from data collection and categorization.

\begin{tabular}{|c|c|c|c|c|}
\hline \multicolumn{2}{|c|}{ Cycle's phase } & \multirow[b]{2}{*}{ Period } & \multirow[b]{2}{*}{ Key institutions } & \multirow[b]{2}{*}{ Main policy, economic, organizational, and scientific-technical features characterizing each period } \\
\hline WRM & WC & & & \\
\hline$\sim-\mathrm{K}$ & & 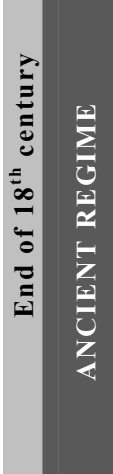 & $\begin{array}{l}\text { Ancient Regime - Local nobility entitled by royal governments or local agreements } \\
\text { to use highly-valuable resources and to regulate the use of the less valuable by } \\
\text { the civilian population. Non-regulated activity of hunters and collectors } \\
\mathbf{1 7 7 8} \text { - Free Trade Decree promoting the reviving of trade at the State level. Seville } \\
\text { and Cádiz lose their monopoly } \\
\mathbf{1 7 8 1} \text { - Founding of the Friends of the Country Society of Sanlúcar de Barrameda } \\
\text { (ancient province in which Doñana was included) for the promotion of economic } \\
\text { development in the region } \\
\mathbf{1 7 9 4 ~ - ~ R o y a l ~ O r d e r ~ a l l o w i n g ~ f o r ~ t h e ~ i m p l e m e n t a t i o n ~ o f ~ t h e ~ f i r s t ~ l a r g e - s c a l e ~} \\
\text { infrastructure in the Guadalquivir Estuary for enhancing navigation, the } \\
\text { Merlina's meander cut (1795) } \\
\mathbf{1 7 9 8} \text { - First Disentitlements allowing the expropriation of clergy's wealth (e.g., } \\
\text { Jesuits, Charity Institutions) }\end{array}$ & $\begin{array}{l}\text { Planning and management based on scattered projects, maintenance of rudimentary infrastructure and } \\
\text { cleaning of natural, accessible water courses } \\
\text { Property system based on multi-functional, community-based or municipal properties for agricultura } \\
\text { activities and low water consumption regimes, immersed in larger crown and nobility properties } \\
\text { Increasing State public deficit } \\
\text { Reviving of the promotion of navigation in the Guadalquivir River (navigability tests, blueprints and } \\
\text { mythology revival), after Seville's loss of trade monopoly and under the Enlightenment's Spirit of } \\
\text { Reform } \\
\text { Beginning of a disentitlement (nationalization-for-privatization) process of low-productivity lands for } \\
\text { increasing their productivity } \\
\text { First public works for enhancing navigation and river defense. Marginal agricultural development }\end{array}$ \\
\hline$\alpha$ & & 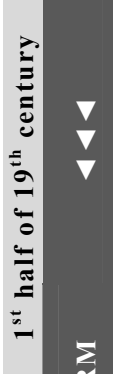 & $\begin{array}{l}\mathbf{1 8 0 5} \text { - Promotion Plan of Sanlúcar Province. First technical planning for the } \\
\text { transformation of region, but almost no practical implementation } \\
\mathbf{1 8 1 4} \text { - Royal Order allowing for the constitution of the Guadalquivir Navigation } \\
\text { Royal Company, preceded by several navigability tests, topographical surveys } \\
\text { and planning } \\
\mathbf{1 8 1 8} \text { - Transaction to the Guadalquivir Navigation Royal Company of one of the } \\
\text { largest marshland territories (Isla Menor) } \\
\mathbf{1 8 1 9 / 1 8 4 9} \text { - Two acts promoting irrigation agriculture among smallholders through } \\
\text { tax exemption } \\
\mathbf{1 8 3 3} \text { - Forestry Bylaws establishing the first protection system for forests }\end{array}$ & $\begin{array}{l}\text { Persistent public deficit, but availability of private investment capital } \\
\text { Developing of formal, but inconsistent policies and investment plans promoting the Guadalquivir Estuary } \\
\text { and the surrounding left- and right-bank marshlands as a territory with a high commercial and economic } \\
\text { potential (navigation, agriculture, colonization, mining) } \\
\text { First works modifying the Guadalquivir River course, through meander cuts and the introduction o } \\
\text { innovative industrial and engineering technologies (steam engine, mining). These processes are } \\
\text { paralleled by the first attempts for drainage and agricultural development, which failed due to lack of } \\
\text { adequate technology (e.g., left-bank Isla Menor marshlands) } \\
\text { Public works for enhancing the Guadalquivir's navigability, granted to companies participated by private } \\
\text { shareholders (e.g., Guadalquivir Navigation Royal Company) }\end{array}$ \\
\hline $\mathrm{r}$ & & 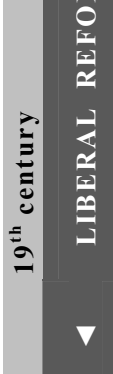 & $\begin{array}{l}\text { 1851-1852 - Series of Royal Orders settling the project for making the } \\
\text { Guadalquivir's navigable } \\
\mathbf{1 8 5 5} \text { - Madoz Disentitlement nationalizing low-yield lands for privatization } \\
\mathbf{1 8 5 9 - 1 8 6 2} \text { - Series of State regulations entitling Forestry Engineering corps to } \\
\text { catalogue excludable areas from the disentitlement process, partly alleviating } \\
\text { forests from devastation (Forestry Catalogue) } \\
\mathbf{1 8 6 5} \text { - Creation of the Hydrographic Demarcations } \\
\mathbf{1 8 6 6} \text { - Water Act declaring water of public domain } \\
\mathbf{1 8 7 0} \text { - Channels and Reservoirs Act granting large public-works companies } \\
\text { perpetuity rights on the use of infrastructures in which they had invested }\end{array}$ & $\begin{array}{l}\text { Increasing sale and/or public auction of properties (marshlands, scrublands and forests) of the so-called } \\
\text { 'dead hands' (clergy and nobility) and beginning of extensive forestry operations (including extensive } \\
\text { clear-cuts) across the State, owing to the disentitlement process (agricultural and paper-industry } \\
\text { development) } \\
\text { Agrarian Technical Reform at the State level - Increasing application of innovative technologies (e.g. } \\
\text { impoldering) for the enhancement of agricultural productivity, based on middle-class and corporate } \\
\text { private capital. High investment costs and long term recouping (land adaptation to irrigation and crop } \\
\text { transformation) slows down technology implementation } \\
\text { Increasing promotion of the need for water control (meander cuts, defense works) and regulation in the } \\
\text { Guadalquivir Estuary (legal system) for enhanced navigation, communication, flood control and disease } \\
\text { prevention }\end{array}$ \\
\hline
\end{tabular}


1870 - Royal Order promoting drainage engineering projects at the Lebrija marshes (most of them finished in 1928, due to inadequate planning and the priority given to navigation policies)

1877 - Act for the enhancement and afforestation of public forests excluded from the disentitlement process

1877 - Royal Order granting the first large-scale drainage works within the Doñan marshlands, at Aznalcázar's Marisma Gallega (failed and reinstated in 1910)

1879 - Water Act giving priority to irrigation agriculture over navigation at the State level -end of laissez-faire policies.

1901 - Creation of the Hidrographic-Forestry Demarcations, precursor of the Water Authorities (1926)

1907 - Colonization Act halting emigration and promoting the cultivation of lowyield lands

1908 - Protective Forestry Act promoting afforestation of public and private forests

1911 - Large Irrigated Lands Act (Gasset Act) establishing the State as the financer and promoter of large public works

1916 - National Parks Act in 1916 creating the National Park’s Trust Boards

1917 to date - Battery of regulations implementing the park-based model

1924 - Royal Order of Ministry of Promotion granting a private financial group the drainage and exploitation rights of the Hinojos marshes ( $\sim 10,000 \mathrm{ha}$. $)$

1926 - Royal Decree for the creation of the modern water authorities.

1927- Creation of the Guadalquivir River Authority

1932 - Irrigation Act increasing the State responsibilities in the development of secondary and complementary public works

1935 - Forest Heritage Act promoting large afforestations with production purposes

1940 - Act entitling Forestry Engineering Corps for heading National Parks planning and management

1941 - Restitution of Forest Heritage Act declaring Huelva province (including Doñana) region of interest for forestry

1957 - Forestry Act entrusting the State Ministry of Agriculture with the stewardship of nature conservation and promoting production-driven planning and technologies

Middle-class actors (naturalists, ornithologists and hunters) promote the Doñana marshes for naturalistic and hunting purposes (e.g. first expeditions of A. Chapman and W.J. Buck) and contribute to establishing its reputation as one of the most important waterfowl reserves in Europe (e.g. A. Machado y Núñez, H. Saunders, and Lord Lilford)

Emergence of an intellectual-scientific movement termed 'Regeneracionismo', aimed at understanding the political, scientific, social and economic causes of Spain's political and economic decline, largely in response to the loss of Spanish overseas territories

Sustained conflicts between Civil and Forestry engineers, rooted in the poor discrimination of their respective responsibilities and their contrasting approaches to planning and management

Key figures of the 'regeneracionismo' describe regional differences in water availability as the main shortcoming for the development of irrigation agriculture, and promote a revised hydraulic-forestry policy as the panacea for economic development

Beginning of the forestry protection-for-conservation policies and regulations in Spain. The Forestry Engineering Corps are entitled to catalogue areas to be protected from colonization and exploitation. Increasing links between nature (forests) conservation and forestry policies

High GDP in Spain during the 1920s

Increasing State interventionism through hydraulic policies and planning (e.g., National Hydraulic Plan of 1902 -Gasset Plan- and 1933), subsequently defended in several National Irrigation Congresses $(1913,1918,1921,1927,1934)$ and paralleled by colonization strategies

Republican attempts for increasing public property in Doñana by declaring the marshes of 'public interest'. However, lobbying by powerful stakeholders and private owners still succeed at promoting the drainage of several hectares of marshes for the culture of rice intended to supply the military

Beginning of an intensive shift in jurisdiction in the private-property system, which increasingly goes to the State

1940s - Increasing improvement of the Spanish economy - high GDP

1940s-1950s - First large-scale projects in Doñana, backed by the Gasset Act of 1911 (e.g. drainage of the Guadiamar River by the Guadalquivir River Authority, executed by public-private contract)

1950s - Massive afforestation projects promoted at the State level, both for production (Forest Heritage/Ministry of Agriculture) and for conservation (Directorate of Forestry/Ministry of Agriculture). 
$\mathbf{\nabla} 1969$ - Doñana Act creating the Doñana National Park (DNP), preceded by the purchase of 6,700 ha of marshlands by the World Wildlife Fund and the creation of the Doñana Biological Reserve and Doñana Biological Station (1964) by the Spanish Research Council

1971 - Decree dictating the merger of the Forest Heritage and the Directorate of Forestry within the Nature Conservation Institute (ICONA), which takes charge of the DNP's stewardship

1972 and 1974 - Two Decrees entitling the Institute for Agrarian Reform and Development (IRYDA) to implement large transformation projects in the marshes surrounding the DNP

1975 - Nature Reserves Act increasing the decision power of local administrations, land owners and the ICONA within the DNP's Trust Board, and favouring the agricultural projects of the IRYDA

$\mathbf{1 9 7 8}$ - Spanish Constitution replacing the authoritarian government by a democratic government

1978 - Doñana Act increasing the Park's surface (50270 ha), and establishing nove guidelines for conservation inside and outside the park, and assigning the direction of the National Park and Biological Reserve to the ICONA (Ministry of Agriculture) and the Doñana Biological Station (Ministry of Education), respectively

1981 - First Doñana Hydraulic Regeneration Plan aimed at the restoration of the main tributaries to the marsh (Guadiamar and Travieso Channels) and the modification of the Gudalquivi River levee, allowing to control the mash inflow and discharges by means of sluices

1983 - Water Act implementing the Hydraulic Public Domain

1984 - First Director Plan of Use and Management of the National Park

1988 - First Director Territorial Plan of Doñana establishing a framework interorganisational and stakeholder coordination in regional planning, and policy development and implementation

1989 - Nature Reserves Inventory Act creating the Doñana Natural Park (54250 ha) buffering the core National Park and the Andalusian Nature Reserves Netwo hencerth stimulating and rinforcing Ahe nat its protection standards and protocols

1993 - First Doñana Sustainable Development Pla

1998 - "Los Frailes" mining accident

1999 - Doñana Nature Reserve Bill aimed at taking over the DNP's managemen 1950s-1960s - First scientific expeditions of key national and international scientists (e.g., J.A. Valverde, F. Bernis), naturalists (e.g., G. Mountfort) and ornithologists (e.g., Roger T. Peterson) to the Doñana marshes, supported by private owners (e.g., M. González) who constituted key stakeholders in the protection-for-conservation processes

1970s - Implementation of the Almonte-Marismas Plan and Guadalquivir-FAO Project (preceded by the discovery and delimitation of the Almonte-Marismas aquifer) for the drainage of 35,000 ha of deltaicand marsh-lands in Doñana, carried out by the IRYDA

1970s - Beginning of a long phase during which the conservation of the Doñana marshes depended on the organisational and personal relationships between the Doñana Biological Station and the ICONA, which was itself facing an internal power-contest between pro-conservation and old-school engineers

1970s - 1978 Doñana Act extending the Park’s surface, to include a strip of marine areas; launching a policy of expropriations to consolidate the public domain over most of its land; instituting an Use and Management Plan; setting the path for the establishment of a Master Plan for the regional coordination of socioeconomic development (e.g., road networks, tourist planning, agricultural and stock farming practices) and nature conservation; and allowing for the creation by law of the Doñana Natural Park buffering the core National Park (Nature Reserves Inventory Act of 1989).

1980s-1990s - Top-down drastic reductions in the irrigable surfaces established in the plans of the prior decades, which become more intensively used due to technological advances

1980s - First, failed hydraulic regeneration projects in Doñan

1970s-1990s - The DNP, fed by intensively modified tributaries and streams, is affected by progressive degradation and punctuated by ecological crises (e.g., waterfowl mortalities, biological invasions, mine pollution) and withstands a considerable number of pressures and threats both outside (e.g. irrigated griculture) and high risk botulism

1990s - First Sustainable Development Plan: increasing adaptation of the development policies to a changing reality, by developing compatible economic and conservation goals

1998 - Mining accident at Los Frailes, after which the Spanish government and the Andalusian government launched the Doñana 2005 and Guadiamar Green Corridor restoration projects respectively 1980s-2000s - The Andalusian Regional Government engages, and finally wins a political and judicial contest to claim jurisdiction over the Doñana National Park from the Spanish (central) Government

$\alpha-\mathrm{r} ? \mathrm{~K}$

* Franco's dictatorship

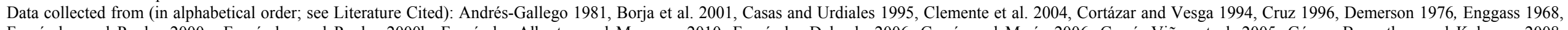

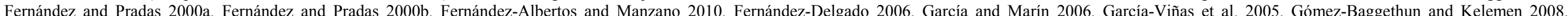
Guadalquivir River Authority 2010, Llamas 1988, Montes et al. 1998, Moral-Ituarte 1991, Moreno 1992, Ojeda 1992, Ojeda and Moral-Ituarte 2004, Orti 1984, Tomás y Valiente 1978, Valverde 2004, Zouwen 2006. 


\section{APPENDIX 2. Detailed description of the specific methods used in the action-research program}

Action research is a methodology based on the collaboration of the researchers and those actors who are at the focus of the research (Susman and Evered 1978, Robson 2002). It is adequate for solving intricate, complex social problems through the collaborative understanding of their underlying causes, as well as of the institutional and organizational change needed to realize such solutions (Robson 2002). In applying this methodology, we assumed that the intervention of "external insiders" with the social expertise needed to promote and facilitate participative and inclusive processes of change, through the use of specific, qualitative methods (Robson 2002), could be instrumental in facilitating the transition from rigid to more flexible and adaptive institutional regimes for water resources management and wetland conservation in Doñana. We employed the following methods:

\section{Actor identification (11/25/2006-05/22/2007)}

Actor identification consisted in the selection and categorization of actors on the basis of previously established criteria (Table A2.1). In particular, we used the historical criterion elaborated after the analysis presented here, Mostert's four criteria for stakeholder identification (Mostert 2006:163), and the three levels of the Institutional Analysis and Development framework (IAD; Kiser and Ostrom 1982, Ostrom 1999, Ostrom 2005). Such criteria allowed us to classify actors in two categories: decision makers (actors with enough power to make a final choice among alternatives in policy making or project implementation processes) and stakeholders (actors who can affect or are affected by the achievement of new policy or project goals, or by those of the action-research program).

Table A2.1. Criteria used for the selection and categorization of actors in our case study.

\begin{tabular}{l}
\hline Historical criterion \\
He/She or his/her organization has historically participated in the past or recent development \\
of the institutional regimes for water resources management or wetland conservation in \\
Doñana. \\
Mostert's criteria \\
\hline A. He/She possess relevant information about the case study. \\
B. He/She can actively contribute to the development of new policy or projects. \\
C. His/Her interests will be directly affected by the action-research program and any \\
D. He/she can obstruct decision making or frustrate policy or project implementation. \\
\hline IAD's levels of inquiry \\
\hline A. Constitutional level (constitutional decisions, actions and rules directly affecting the \\
B. Collective-choice level). \\
C. Offecting the operational level). \\
\hline \hline
\end{tabular}


Following these criteria, we identified a total of 40 actors, of which 34 where finally contacted (the other 6 were either unavailable, retired or on sabbatical). 25 of them were available for interviewing in the first phase (1h on average by the same researcher), 7 took part in the uncertainty workshop, and 24 took part in the research-management workshop (though only 15 participated in the Group Model Building session; see Table A2.2 and the Workshops section below). All actors (38\% decision makers, 62\% stakeholders) met our historical criterion, and at least two of Mostert's criteria at any of Ostrom's levels. Decision makers met at least three specific Mostert's criteria (B, $\mathrm{C}$ and D) (Table A2.2). Key decision makers predominantly belonged to agencies with direct management duties over the Doñana Nature Reserve, such as its Administration Office (Regional Ministry of Environment), the Doñana Biological Station (Ministry of Education and Science) and the Guadalquivir River Authority (Ministry of Environment). Stakeholders included officers from the Andalusian Ministry of Environment (Andalusian Water Agency and Nature Reserves Network), academics from (national and Andalusian) universities and research agencies, and the WWF.

Table A2.2. Identified actors (UW = uncertainty workshop, RMW = research-management workshop, DM = decision maker, $\mathrm{SH}$ = stakeholder).

\begin{tabular}{|c|c|c|c|c|c|c|c|c|}
\hline \multirow[b]{2}{*}{ ID } & \multirow[b]{2}{*}{ Organization } & \multicolumn{4}{|c|}{ Criteria and category } & \multirow[b]{2}{*}{ Interview } & \multirow[b]{2}{*}{ UW } & \multirow[b]{2}{*}{ RMW } \\
\hline & & Historical & Mostert & Ostrom & Category & & & \\
\hline A1 & Doñana Nature Reserve & Yes & A, B, C, D & A, B, C & DM & Yes & No & Yes \\
\hline A2 & Doñana Nature Reserve & Yes & A, B, C, D & $\mathrm{B}, \mathrm{C}$ & DM & Yes & No & Yes \\
\hline A3 & Doñana Nature Reserve & Yes & A, B, C, D & $\mathrm{B}, \mathrm{C}$ & DM & Yes & No & Yes $(+)$ \\
\hline A4 & Doñana Nature Reserve & Yes & A, B, C, D & $\mathrm{B}, \mathrm{C}$ & $\mathrm{DM}$ & Yes & Yes & No \\
\hline A5 & Doñana Nature Reserve & Yes & A, B & $\mathrm{C}$ & $\mathrm{SH}$ & No & No & Yes $(+)$ \\
\hline A6 & Doñana Biological Station & Yes & A, B, C, D & A, B, C & DM & Yes & No & No \\
\hline A7 & Doñana Biological Station & Yes & A, B, C & $\mathrm{B}, \mathrm{C}$ & DM & No & No & Yes \\
\hline A8 & Doñana Biological Station & Yes & A, B & $\mathrm{C}$ & $\mathrm{SH}$ & Yes & No & Yes \\
\hline A9 & Doñana Biological Station & Yes & A, B & $\mathrm{C}$ & $\mathrm{SH}$ & Yes & No & No \\
\hline A10 & Doñana Biological Station and Reserve & Yes & A, B, C, D & $\mathrm{B}, \mathrm{C}$ & DM & Yes & No & Yes $(+)$ \\
\hline A11 & Doñana Biological Station & Yes & A, B & $\mathrm{C}$ & $\mathrm{SH}$ & Yes & No & No \\
\hline A12 & Doñana Biological Station and Reserve & Yes & A, B & $\mathrm{C}$ & $\mathrm{SH}$ & Yes & No & Yes $(+)$ \\
\hline A13 & Doñana Biological Station & Yes & A, B, C, D & $\mathrm{B}, \mathrm{C}$ & $\mathrm{DM}$ & Yes & No & No \\
\hline A14 & Doñana Biological Station & Yes & A, B & $\mathrm{C}$ & $\mathrm{SH}$ & No & No & Yes \\
\hline A15 & Doñana Biological Station & Yes & A, B & $\mathrm{C}$ & $\mathrm{SH}$ & Yes & Yes & Yes $(+)$ \\
\hline A16 & Doñana Biological Station & Yes & A, B, C, D & $\mathrm{B}, \mathrm{C}$ & DM & Yes & No & No \\
\hline A17 & Doñana Biological Station & Yes & A, B & $\mathrm{C}$ & $\mathrm{SH}$ & Yes & Yes & Yes $(+)$ \\
\hline A18 & Doñana Biological Station & Yes & A, B & C & $\mathrm{SH}$ & No & No & Yes $(+)$ \\
\hline A19 & Doñana Biological Station & Yes & A, B & $\mathrm{C}$ & $\mathrm{SH}$ & No & No & Yes $(+)$ \\
\hline A20 & Doñana Biological Station & Yes & A, B & $\mathrm{C}$ & $\mathrm{SH}$ & No & No & Yes \\
\hline A21 & $\begin{array}{l}\text { Guadalquivir River Authority - Water } \\
\text { Planning Office }\end{array}$ & Yes & A, B, C, D & A, B, C & $\mathrm{DM}$ & No & Yes & Yes $(+)$ \\
\hline A22 & $\begin{array}{l}\text { Guadalquivir River Authority - Seville Area } \\
\text { Office }\end{array}$ & Yes & A, B, C, D & A, B, C & DM & Yes & Yes & Yes $(+)$ \\
\hline A23 & $\begin{array}{l}\text { Andalusian Water Institute - Doñana } 2005 \\
\text { Project }\end{array}$ & Yes & A, B, C, D & A, B, C & $\mathrm{DM}$ & Yes & No & No \\
\hline A24 & $\begin{array}{l}\text { Andalusian Water Institute - Doñana } 2005 \\
\text { Project }\end{array}$ & Yes & A, B & $\mathrm{B}, \mathrm{C}$ & $\mathrm{SH}$ & No & Yes & No \\
\hline A25 & $\begin{array}{l}\text { Andalusian Water Agency - Doñana } 2005 \\
\text { Project }\end{array}$ & Yes & A, B & B & $\mathrm{SH}$ & Yes & No & Yes $(+)$ \\
\hline
\end{tabular}


Table A2.2 (cont'd). Identified actors (UW = uncertainty workshop, RMW = research-management workshop, DM = decision maker, $\mathrm{SH}=$ stakeholder).

\begin{tabular}{|c|c|c|c|c|c|c|c|c|}
\hline \multirow[b]{2}{*}{ ID } & \multirow[b]{2}{*}{ Organization } & \multicolumn{4}{|c|}{ Criteria and category } & \multirow[b]{2}{*}{ Interview } & \multirow[b]{2}{*}{ UW } & \multirow[b]{2}{*}{ RMW } \\
\hline & & Historical & Mostert & Ostrom & Category & & & \\
\hline A26 & $\begin{array}{l}\text { Andalusian Water Agency - Doñana } 2005 \\
\text { Project }\end{array}$ & Yes & A, B & $\mathrm{C}$ & $\mathrm{SH}$ & Yes & No & No \\
\hline A27 & $\begin{array}{l}\text { Andalusian Nature Reserves Network - } \\
\text { Directorate General }\end{array}$ & Yes & A, B, C, D & $\mathrm{A}, \mathrm{B}, \mathrm{C}$ & $\mathrm{DM}$ & Yes & No & Yes \\
\hline A28 & University of Seville - Doñana 2005 Project & Yes & A, B & $\mathrm{C}$ & $\mathrm{SH}$ & Yes & No & Yes $(+)$ \\
\hline A29 & University of Seville & Yes & A, B & $\mathrm{C}$ & $\mathrm{SH}$ & Yes & No & Yes \\
\hline A30 & University of Huelva - Doñana 2005 Project & Yes & A, B & $\mathrm{C}$ & $\mathrm{SH}$ & Yes & No & Yes $(+)$ \\
\hline A31 & University of Córdoba - Doñana 2005 Project & Yes & $\mathrm{A}, \mathrm{B}$ & $\mathrm{C}$ & $\mathrm{SH}$ & Yes & No & No \\
\hline A32 & $\begin{array}{l}\text { Polytechnic University of Catalonia - Doñana } \\
2005 \text { Project }\end{array}$ & Yes & A, B & $\mathrm{C}$ & $\mathrm{SH}$ & No & No & Yes \\
\hline A33 & $\begin{array}{l}\text { Institute for Prospective Technological } \\
\text { Studies (European Commission's Joint } \\
\text { Research Centre) }\end{array}$ & Yes & A, B & $\mathrm{C}$ & $\mathrm{SH}$ & Yes & No & No \\
\hline A34 & WWF/Adena Doñana Office & Yes & A, B, C & A, B & $\mathrm{SH}$ & Yes & No & Yes $(+)$ \\
\hline- & $\begin{array}{l}\text { Mediterranean Institute for Advanced Studies } \\
\text { - Doñana } 2005 \text { Project }\end{array}$ & - & - & - & - & - & Yes & - \\
\hline- & Sierra Nevada Nature Reserve & - & - & - & - & - & - & Yes (+) \\
\hline Totals & 34 (latter two excluded from count) & \multicolumn{4}{|c|}{13 DM (38\%) and 21 SH (62\%) } & 25 & 7 & $24(15)$ \\
\hline
\end{tabular}

$(+)$ Actor that stayed and participated in the GMB (third) session of the RMW.

$†$ L. Santamaría was invited externally by organizer N. Insendahl to participate in the UW (co-organized with P. F. Méndez), before she joined the research program; both then acted as organizers together with P. F. Méndez and J. Amezaga in the RMW.

\section{Semi-structured, open-ended interviews - question guides (06/19/2007-10/26/2007)}

1. What is the function of your organization?

Primary themes (non-consecutive, alternative):

- Function in the field of water resources in the Guadalquivir Estuary.

- Function in the field of wetland conservation in the Guadalquivir Estuary.

- More specific function within the Doñana Nature Reserve.

2. What type of organization is it (public, private, non-profit)?

3. Which are your duties within your organization?

4. What is your general perspective about water resources management in Doñana and the Guadalquivir Estuary?

Primary themes (subsequent and consecutive):

- General perspective and opinion.

- EU's policies and legislation.

- National and regional policies and legislation.

- Research and management.

- Operational management. 
5. What is your general perspective about wetland conservation in Doñana?

Primary themes (subsequent and consecutive):

- General perspective and opinion.

- EU's policies and legislation.

- National and regional policies and legislation.

- Research and management.

- Operational management.

Let’s talk about the “Doñana 2005” Eco-Hydraulic Restoration Project.

6. What problem was being assessed?

7. What is your general perspective about the management of the Doñana 2005 Project?

Primary themes (subsequent and consecutive):

- General perspective and opinion.

- Research and management.

- Operational management.

8. More specifically, what is your general perspective of the restoration action carried out at the Caracoles Estate which, as you might know, was designed under adaptive management tenets?

Primary themes (subsequent and consecutive):

- General perspective and opinion.

- Research and management.

- Operational management.

We define institutions as "the prescriptions that humans use to organize all forms of organized, established, social procedures (formal and informal rules, organizations, epistemological domains and technologies)” (Brief explanation of definition and specific elements if requested).

9. Which were the main opportunities and barriers that such action encountered in the institutional realm?

Primary themes (non-consecutive, alternative):

- Formal (e.g., legislation, policies) and informal rules (e.g. innovation networks, lobbies).

- Organizations (e.g., research organizations -universities, institutes-, management agencies).

- Scientific-technical perspectives (as a surrogate of epistemological domains; e.g., command-and-control approaches, ecosystem-based and adaptive management).

- Technologies (e.g., information technologies).

\section{$\underline{\text { Workshops }}$}

\section{Uncertainty workshop (12/05/2007)}

The uncertainty workshop aimed at preliminarily identifying uncertainties in water management and nature conservation in the Doñana Nature Reserve and the Guadalquivir Estuary from the perspective of practitioners. It was held as a focus group, involving 7 key actors for water management and conservation in the Guadalquivir estuary. The workshop first assessed how the 
participants perceived and framed uncertainty. In an open discussion, they identified several situations of uncertainty relevant to their professional work and, on the basis of these situations of uncertainty, shared parameters were interactively developed making use of the card-sorting method. During the workshop, the need to explicitly take uncertainties into account was made explicit and a reflection process about the approaches required to make such realization operative was instigated. The workshop showed that there is a considerable variety of uncertainties that actors in water management have to deal with. Their conceptualization by the different actors was explicitly captured and reflected in a final list of 13 uncertainty situations (Table A2.3). This exercise and the derived set of parameters constituted a first step towards making approaches for dealing with uncertainty more explicit and structured in our case study (see Isendahl et al. 2010 for a more detailed description of the workshop organization and results).

Table A2.3. Uncertainty workshop. Upper panel: situations of uncertainty relevant to the professional work of the participants. Lower panel: shared parameters.

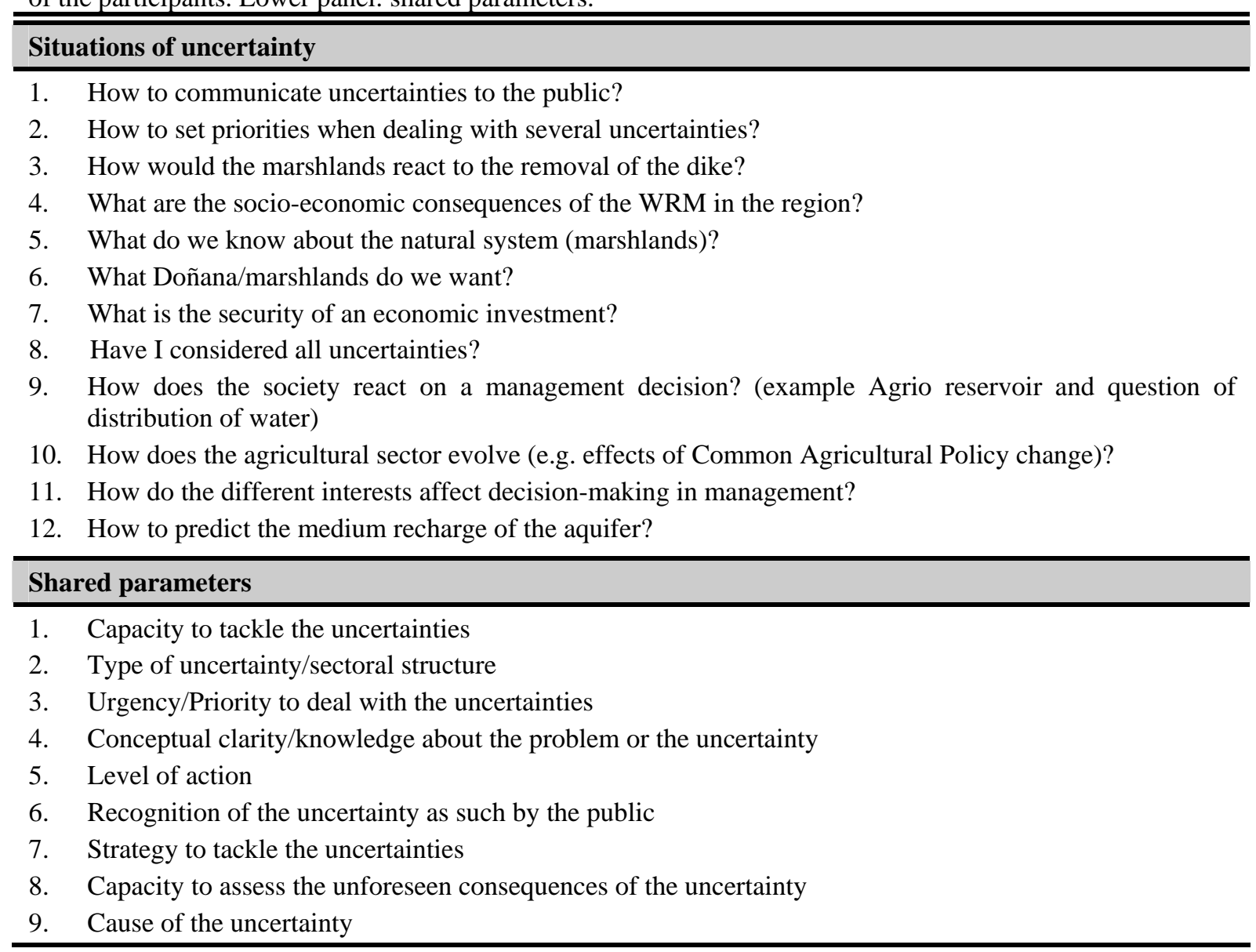

\section{Research-management workshop (04/02/2008)}

The research-management workshop involved a group of 24 of the identified actors (Table A2.2) and focused on the improvement of the research-management interface in the Doñana Nature Reserve and the Guadalquivir Estuary. As has been shown, it constitutes a critical element in the region, due to the historical weight of the competitive (often conflictive) trade-off between water resources management and wetland conservation goals. Prior to the workshop, and based on our preliminary analysis of the interviews and the results of the uncertainty workshop, the following 
management and governance problems were listed in a whiteboard (placed visible and presented to all the participants at the outset of the workshop):

- The absence of a strategic framework for the region.

- $\quad$ The lack of water management and wetland conservation goals.

- $\quad$ The lack of a shared model of the structure and functioning of the Doñana wetland ecosystems.

- The ignorance of key uncertainties.

- The absence of pre-defined goals for monitoring programs (in spite of their long-term and coordinated character).

- The absence of evaluation and learning mechanisms (institutions, protocols, standards, coordinating individuals, champions, etc.).

The workshop was divided in three parts. Firstly, we introduced our action-research program and presented adaptive management as a potential tool to introduce dynamism and learning capacity into the research-management interface. As an example, we provided an overview of the challenges and successes faced by a number of projects that had applied adaptive management elsewhere (with an emphasis on British Columbia, Canada; see Méndez et al. 2010 for a review). We also summarized the results of the uncertainty workshop.

Secondly, we organized four thematic talks (about nature conservation, research, water management and hydro-ecological restoration), presented by key decision makers and followed by facilitated discussion. In the discussion, several problems related to conservation, research and water management in the Doñana Nature Reserve emerged. The session concluded with the synthesis of such problems, their conversion into objectives and the elaboration of a shared list of recommendations to foster the improvement of the research-management interface (see Table 4 from main text).

Thirdly, we organized a session of participatory modeling (with only 15 of the initial participants, owing to agenda constraints of the rest) that was performed in two separated groups, respectively focused on two key components of the management of Doñana's aquatic ecosystems: water and vegetation. These elements had been identified during the preceding interviews and historical analysis, as being both central to the management of these ecosystems and inter-related to most other relevant elements. We used Group Model Building as a method facilitating the sessions (Vennix 1996, Andersen et al. 1997). Each group, guided and moderated by a facilitator, worked on jointly building one causal model following a classic approach - focusing on simple mechanisms to build causal relationships (see Vennix 1996). Both models were then presented in a plenary session and used for group discussion.

The "water-management group" built a model aimed at achieving "sustainable water management regimes that ensure the long-term conservation of the biodiversity hosted by the Doñana Nature Reserve marsh/wetland ecosystems" (Fig. A2.1), whereas the "vegetation management group" built a model aimed at achieving "the sustainable management of the vegetation of the Doñana Nature Reserve marsh/wetland ecosystems (and its grazers), in order to assure the conservation of the biodiversity hosted by them" (Fig. A2.2). Participants were asked to identify first-order (directly influencing the main goal) and second-order (directly influencing first-order factors) drivers of change towards the accomplishment of the main goals (Table A2.4). Additional goals during the discussions were (1) to work towards a shared understanding of water management and nature conservation in the Doñana region, and (2) to collectively identify options of institutional change. 
Finally, both groups were asked to identify key sources of uncertainty in the modeled subsystems (water and vegetation) - which were contrasted with those reported in the uncertainty workshop.

Table A2.4. Synthesis of first-order and second-order causes recognized as drivers of change towards the accomplishment of the main goal, by the participants in the research-management workshop's Group Model Building sessions.

\begin{tabular}{|c|c|c|c|}
\hline Session & Main goal & First-order causes & Second-order causes \\
\hline Water & $\begin{array}{l}\text { Sustainable water } \\
\text { management regimes that } \\
\text { ensure the long-term } \\
\text { conservation of the } \\
\text { biodiversity hosted by the } \\
\text { DNR's marsh/wetland } \\
\text { ecosystems. }\end{array}$ & $\begin{array}{l}\text { - The improvement of knowledge on } \\
\text { ecosystem functioning. } \\
\text { - The promotion of social dialog in } \\
\text { the affected region. } \\
\text { - The clear definition of management } \\
\text { and conservation criteria (e.g. water } \\
\text { quantity and quality needs). } \\
\text { - The improvement of inter-agency } \\
\text { and trans-disciplinary coordination. } \\
\text { - The management of the 'Doñana } \\
\text { sub-basin' }\end{array}$ & $\begin{array}{l}\text { - The implementation of long- } \\
\text { term monitoring programs. } \\
\text { - The free availability and transfer } \\
\text { of results from these programs. } \\
\text { - The development of standards } \\
\text { and technologies for information } \\
\text { sharing and transference. } \\
\text { - Socioeconomic research. } \\
\text { - Political support (was envisaged } \\
\text { as instrumental) for the } \\
\text { elaboration of collective, shared } \\
\text { management and conservation } \\
\text { criteria. } \\
\text { - Environmental education (driver } \\
\text { of change affecting the whole } \\
\text { model). }\end{array}$ \\
\hline Vegetation & $\begin{array}{l}\text { Sustainable management of } \\
\text { the vegetation of the DNR's } \\
\text { marsh/wetland ecosystems } \\
\text { (and its grazers), in order to } \\
\text { ensure the conservation of } \\
\text { the biodiversity hosted by } \\
\text { them. }\end{array}$ & $\begin{array}{l}\text { - The adjustment of the herbivore } \\
\text { load to the temporal fluctuations } \\
\text { and spatial variation in the marsh's } \\
\text { carrying capacity. } \\
\text { - The adequate implementation, on } \\
\text { the ground, of the DNR's planning } \\
\text { and management instruments. } \\
\text { - The collective building of a } \\
\text { system's functioning model } \\
\text { (including hydrologic, climatic and } \\
\text { vegetation dynamics). } \\
\text { - The introduction of preventive } \\
\text { management strategies (e.g. risk } \\
\text { management, prevention and } \\
\text { control of alien species). } \\
\text { - The establishment of water quantity } \\
\text { and quality criteria. }\end{array}$ & $\begin{array}{l}\text { - The reduction of erosion through } \\
\text { hydraulic restoration of streams. } \\
\text { - The improvement of agricultural } \\
\text { planning. } \\
\text { - The re-evaluation and } \\
\text { improvement of the existing } \\
\text { legal instruments. } \\
\text { - Knowledge generation and } \\
\text { information gathering through } \\
\text { research and monitoring. } \\
\text { - Environmental education (driver } \\
\text { of change affecting the whole } \\
\text { model). } \\
\text { - Future reforms of EU’s policies } \\
\text { (e.g., Water Framework } \\
\text { Directive, Common Agricultural } \\
\text { Policy) (driver of change } \\
\text { affecting the whole model). }\end{array}$ \\
\hline
\end{tabular}


Fig. A2.1. Water-management model.

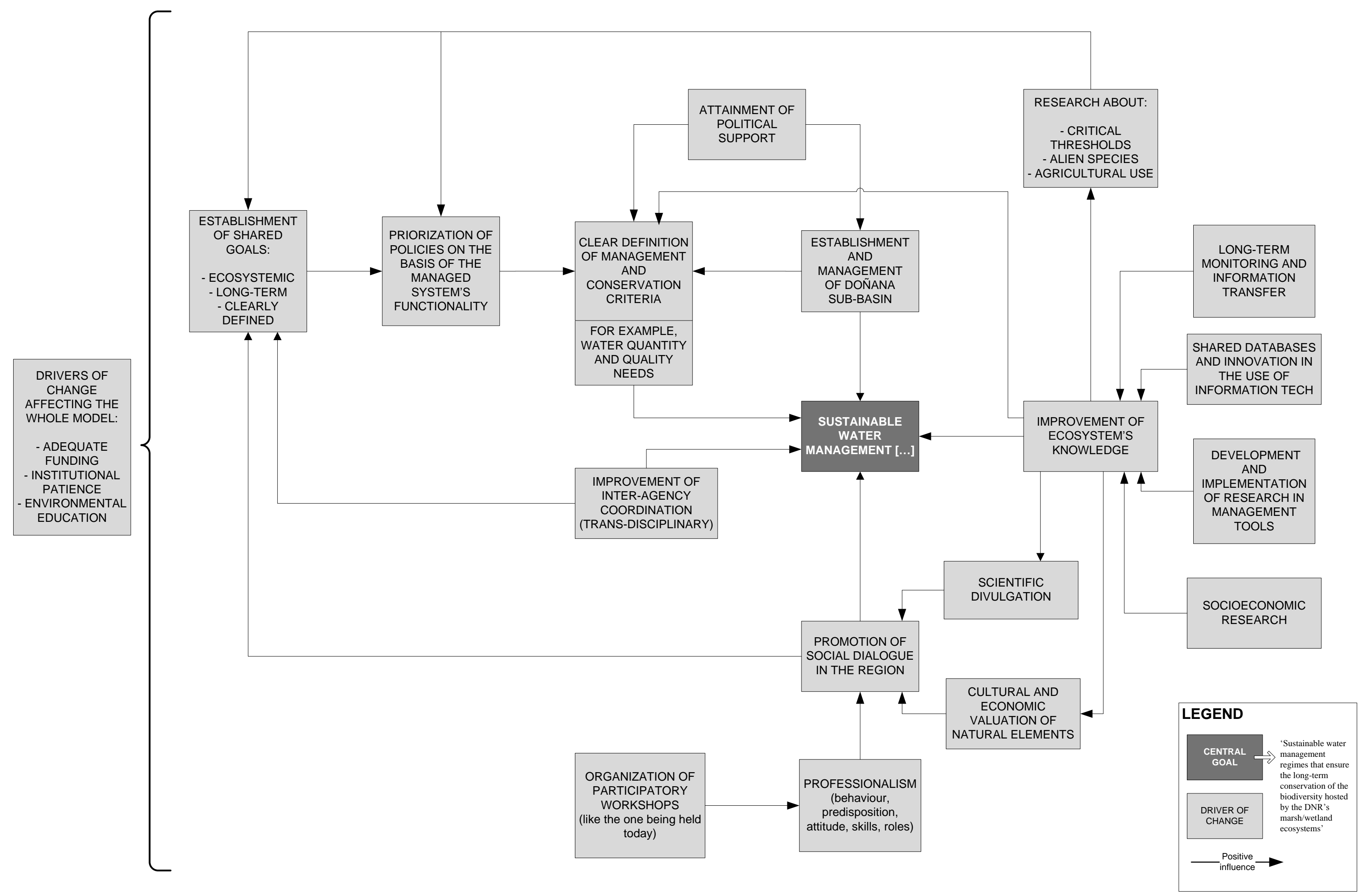




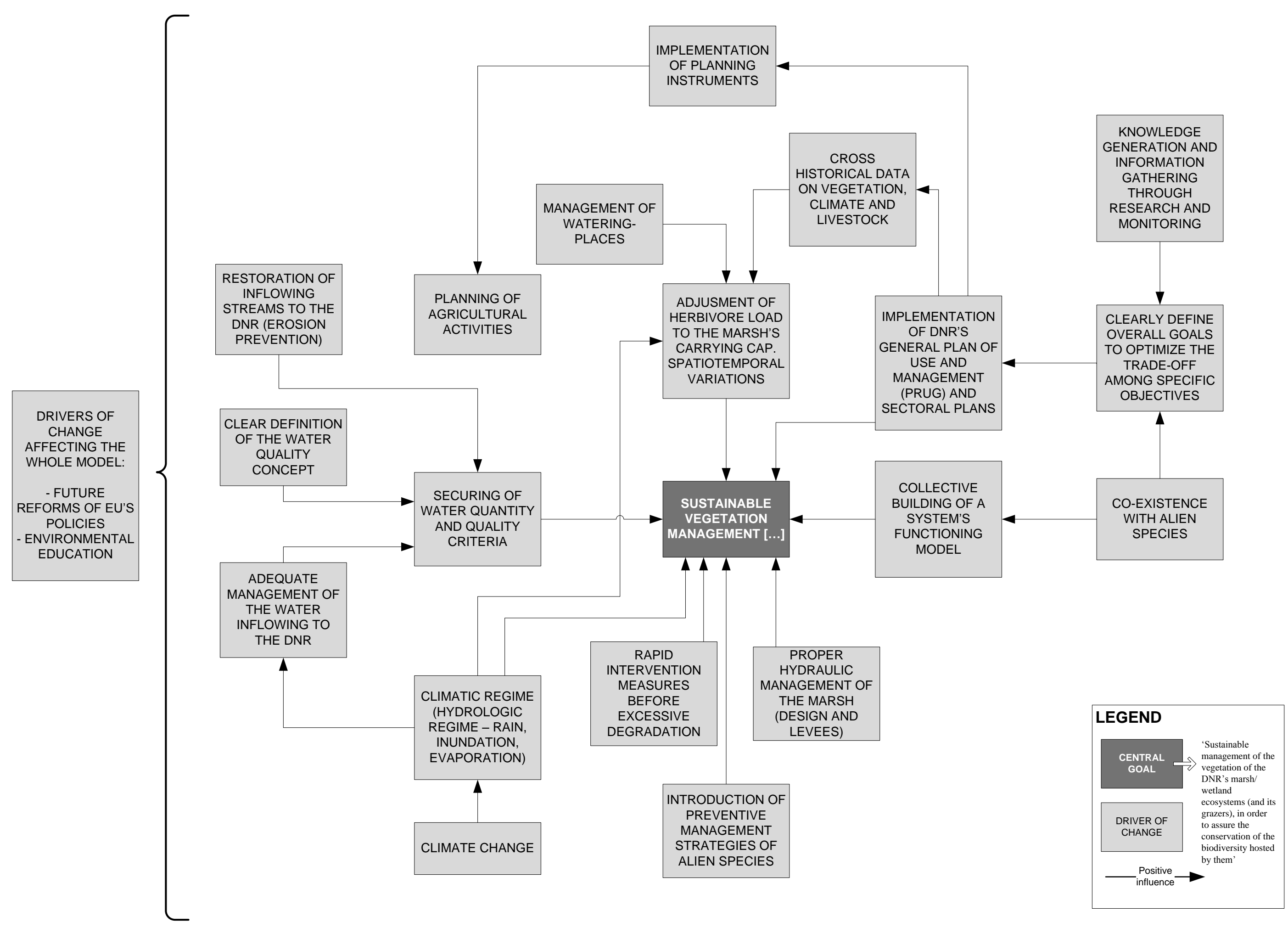

